University of Wollongong

Research Online

Faculty of Science, Medicine and Health -

Papers: Part B

Faculty of Science, Medicine and Health

$1-1-2020$

\title{
What is underneath the juvenile Ordovician Macquarie Arc (eastern Australia)? A question resolved using Silurian intrusions to sample the lower crust
}

Qing Zhang

University of Wollongong, qing@uow.edu.au

Allen Phillip Nutman

University of Wollongong, anutman@uow.edu.au

Solomon Buckman

University of Wollongong, solomon@uow.edu.au

Vickie C. Bennett

vickie.bennett@anu.edu.au

Follow this and additional works at: https://ro.uow.edu.au/smhpapers1

Publication Details Citation

Zhang, Q., Nutman, A. P., Buckman, S., \& Bennett, V. C. (2020). What is underneath the juvenile Ordovician Macquarie Arc (eastern Australia)? A question resolved using Silurian intrusions to sample the lower crust. Faculty of Science, Medicine and Health - Papers: Part B. Retrieved from https://ro.uow.edu.au/ smhpapers1/1126

Research Online is the open access institutional repository for the University of Wollongong. For further information contact the UOW Library: research-pubs@uow.edu.au 


\title{
What is underneath the juvenile Ordovician Macquarie Arc (eastern Australia)? A question resolved using Silurian intrusions to sample the lower crust
}

\author{
Abstract \\ 2020 International Association for Gondwana Research The Ordovician intra-oceanic Macquarie Arc of \\ eastern Australia collided with the eastern Gondwanan margin at 440 Ma. However, the deep crustal \\ architecture resulting from this assembly is poorly known. This is addressed here by a zircon U-Pb-Hf \\ study of the post-assembly Silurian Browns Creek Intrusive Complex and Davies Creek Granite dykes that \\ intrude into the arc, and not adjacent Gondwanan sedimentary sequences. Zircon U[sbnd]Pb dating \\ integrated with CL imagery indicate two igneous phases at 430-437 Ma and 420-426 Ma and a zircon \\ recrystallisation phase at 395-396 Ma attributed to a late thermal event. The magmatic zircon initial $\varepsilon \mathrm{Hf}$ \\ values vary from -5.1 to +4.7 . This signature indicates the source of these granitic rocks is strongly \\ influenced by typical pre-Silurian Gondwanan material. Granitic rock and zircon compositions \\ demonstrate that at the likely temperature of the Silurian granitic magma, especially the Davies Creek \\ Granite dykes, inherited source zircons were mostly dissolved, explaining the absence of pre-Ordovician \\ xenocrysts within the zircon population. The unradiogenic $\mathrm{Hf}$ isotopic signatures preserved in the Silurian \\ magmatic zircons demonstrate the contribution of Gondwanan crustal material to the magma source \\ region. These results support the interpretation of the Macquarie Arc as an intra-Panthalassa ocean \\ allochthon, emplaced and resting over the edge of Gondwanan crystalline basement, possibly including \\ the continent-derived sedimentary rocks of the Adaminaby Group.

\section{Publication Details} \\ Zhang, Q., Nutman, A., Buckman, S. \& Bennett, V. (2020). What is underneath the juvenile Ordovician \\ Macquarie Arc (eastern Australia)? A question resolved using Silurian intrusions to sample the lower \\ crust. Gondwana Research, 81 362-377.
}


1 What is Underneath the Juvenile Ordovician Macquarie Arc

2 (Eastern Australia)? A Question Resolved using Silurian

3 Intrusions to Sample the Lower Crust

4

5

\author{
Qing Zhang a*, Allen Nutman a, Solomon Buckman a , Vickie C. Bennett ${ }^{\text {b }}$ \\ *Corresponding author: qz576@uowmail.edu.au
}

a. School of Earth, Atmospheric and Life Sciences, University of Wollongong, 2522, NSW, Australia

b. Research School of Earth Sciences, Australian National University, 2061, ACT, Australia

Abstract

The Ordovician intra-oceanic Macquarie Arc of eastern Australia collided with the eastern Gondwanan margin at 440 Ma. However, the deep crustal architecture resulting from this assembly is poorly known. This is addressed here by a zircon $\mathrm{U}-\mathrm{Pb}-\mathrm{Hf}$ study of the post-assembly Silurian Browns Creek Intrusive Complex and Davies Creek Granite dykes that intrude into the arc, and not adjacent Gondwanan sedimentary sequences. Zircon U-Pb dating integrated with CL imagery indicate two igneous phases at 430-437 Ma and 420-426 Ma and a zircon recrystallisation phase at 395-396 Ma attributed to a late thermal event. The magmatic zircon initial $\varepsilon \mathrm{Hf}$ values vary from -5.1 to +4.7 . This signature indicates the source of these granitic rocks is strongly influenced by typical pre-Silurian Gondwanan material. Granitic rock and zircon compositions demonstrate that at the likely temperature of the Silurian granitic magma, especially the Davies Creek Granite dykes, inherited source zircons were mostly dissolved, explaining the absence of pre-Ordovician xenocrysts within the zircon population. The unradiogenic Hf isotopic signatures preserved in the Silurian magmatic zircons demonstrate the contribution of Gondwanan crustal material to the magma source region. These 
results support the interpretation of the Macquarie Arc as an intra-Panthalassa ocean allochthon, emplaced and resting over the edge of Gondwanan crystalline basement, possibly including the continent-derived sedimentary rocks of the Adaminaby Group.

Key words: Browns Creek Intrusive Complex, Davies Creek Granite dykes, zircon U-Pb-Hf isotopes, Macquarie Arc, basement

\section{Graphic abstract:}

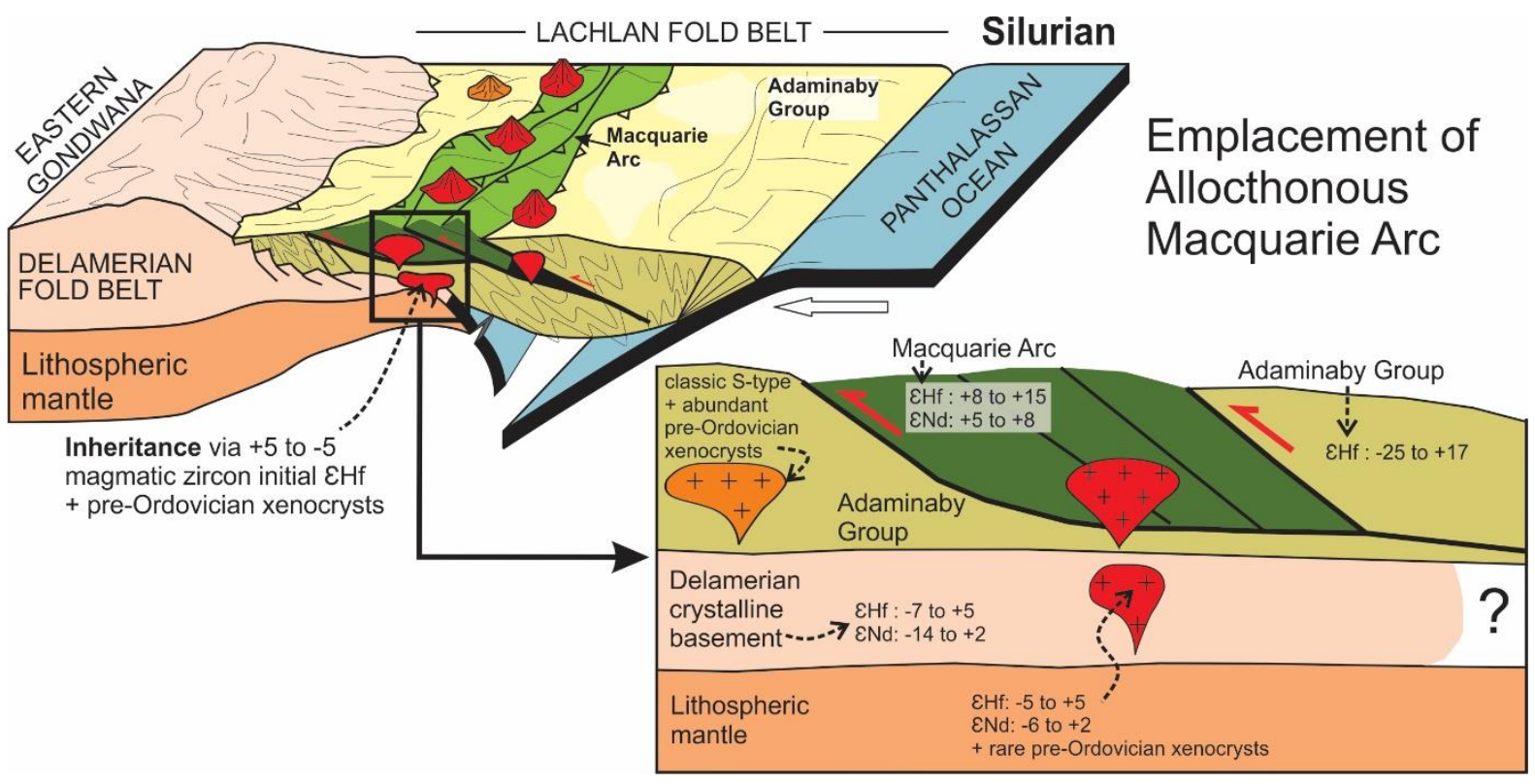

\section{Introduction}

Intra-oceanic island arcs are key components in the progressive growth of eastern Gondwana, such as the Ordovician Macquarie Arc within the Lachlan Orogen, eastern Australia (Crawford et al., 2007; Glen et al., 2009; Meffre et al., 2007). Thus, understanding the emplacement of the intra-oceanic island arcs is important in any model proposed for the growth and stabilisation of eastern Gondwana. The Macquarie Arc is in faulted contact with coeval quartz-rich turbidites of the Adaminaby Group, which developed as a passive margin sequence along the east Gondwana continental margin (Glen et al., 2002; Meffre et al., 2007) (Fig. 1a, b). Debates exist as to the allochthoneity of the Macquarie Arc with the following three possibilities: (1) a continuously west-dipping subduction zone associated with a retreating 
accretionary orogeny, with the Macquarie Arc representing an autochthonous marginal back arc to proximal island arc system (Cawood et al., 2009; Collins, 2002; Glen, 2013), (2) collision of an allochthonous, exotic island arc formed within the Panthalassa Ocean via east-dipping a subduction flip and continental arc volcanism (Aitchison and Buckman, 2012), or (3) rotation of an arc off-board of Gondwana, leading to its accretion onto the continental margin (Fergusson and Colquhoun, 2018; Gray and Foster, 2004). The first two of these scenarios are summarised in Figure 2, with indication of how they can be differentiated via the U-Pb-Hf zircon study of post accretion assembly Silurian granitic rocks.

A recent study reinforced that the Macquarie Arc was initiated within the Panthalassa ocean remote from Gondwana, as demonstrated by the juvenile zircons (initial $\varepsilon \mathrm{Hf}$ $=+12$ to +14 ) from the early arc samples (Zhang et al., 2019a). However, details of the amalgamation of the arc with Gondwana and the resulting deep crustal architecture were unresolved. This study targets the Silurian-Devonian granitic rocks that intrude the Macquarie Arc in order to 'sample' their deep crustal source region. This technique is used because granitic magmas carry the isotopic and chemical characteristics from their source regions, which could also be influenced by their surrounding country rocks via assimilation, providing a window to the underlying basement (e.g., Baadsgaard et al., 1986; Chappell et al., 1988; Jeon and Williams, 2018; Moorbath et al., 1981). Integrating whole rock isotopic signatures with U$\mathrm{Pb}$-Hf zircon studies is providing ever more high-resolution information on the deep crustal sources of granites in eastern Australia (Jeon et al., 2012). This technique, U-Pb-Hf isotopic studies on the post-collision intrusions, could also be widely applied to any exotic terranes, to constrain the emplacement mechanism (e.g., Chappell et al., 1988; Nutman et al., 2008). represents a vast klippe that overlies the Gondwanan continental margin and is likely to display 
continental inheritance within the Silurian granitic bodies cutting it (Fig. 2b). This study focusses on the Browns Creek Intrusive Complex and Davies Creek Granite (dykes) because they intrude the Macquarie Arc and are located at least 10-20 km from exposures of the quartz turbidites of the Gondwanan-sourced Adaminaby Group (Fig. 1c). These two intrusions compositionally plot on the I-, S-type granite transitional line of Chappell et al. (1988). We combine the petrology, zircon $\mathrm{U}-\mathrm{Pb}-\mathrm{Hf}$ isotopes, whole rock geochemistry and previous zircon $\mathrm{U}-\mathrm{Pb}$ and $\mathrm{Sr}-\mathrm{Nd}$ studies to establish the deep crustal structure under the Macquarie Arc.

\section{Geological setting}

The Tasmanides represents one sector of the great Terra Australis Orogen that developed as an $\sim 18,000 \mathrm{~km}$ long orogen on the Pacific margin (Cawood, 2005), and records Cambrian to Triassic crustal evolution (e.g., Glen, 2005; Rosenbaum, 2018). The OrdovicianDevonian Lachlan Orogen within the southeastern Tasmanides (Fig. 1a) is dominated by massive Ordovician quartz-rich turbidites of the Adaminaby Group, coeval intra-oceanic Macquarie Arc volcanic rocks (Glen, 2005; Meffre et al., 2007; Zhang et al., 2019a), and Silurian-Devonian igneous and sedimentary rocks (Champion, 2016; Fergusson, 2010; Foster and Gray, 2000; Glen, 2005; Rosenbaum, 2018; VandenBerg, 2000). The Macquarie Arc is in faulted contact to the east and west with the quartz-rich turbidites (Fig. 1b, c; Fergusson and Colquhoun, 2018; Meffre et al., 2007).

The Browns Creek Intrusive Complex was originally named as 'Carcoar Granodiorite' (Pogson and Watkins, 1998 and references therein), which covers most parts of the intrusive complex, except the more mafic phase 'Long Hill Diorite' near Browns Creek (Fig. 1c; Fig.S1; Pogson and Watkins, 1998). This paper uses term 'Browns Creek Intrusive Complex', after Kovacs (2000), including the Carcoar Granodiorite, Long Hill Diorite in the north-western part of the intrusion, and the Browns Creek dykes (Ming Dyke Group), some of 
which intruded into the Ordovician Cowriga Limestone Member (Figs. 1, 3; Fig. S1). It crops out over $\sim 87 \mathrm{~km}^{2}$ and lies to the southwest of Blayney, where it intrudes Ordovician Macquarie Arc units including the Stokefield Metagabbro, Blayney Volcanics, Cowriga Limestone Member and Coombing Formation (Figs. 1, 3; Fig. S1; Pogson and Watkins, 1998). It is faulted against the Late Ordovician Tallwood Monzonite and the Weemalla Formation along the Carcoar Fault to the west (Fig. S1; Fig. 3; Pogson and Watkins, 1998). This intrusion may have experienced up to three deformation events (Lennox et al., 1998).

The Davies Creek Granite occurs to the northeast of Rockley, and includes two plutons with surface expressions of $\sim 70 \mathrm{~km}^{2}$ and $15 \mathrm{~km}^{2}$, and is cut by a series of north-south striking Carboniferous dolerite dykes (Fig. S1; Colquhoun et al., 2017) and some syn-tectonic granophyre dykes (Fowler and Lennox, 1992). These plutons intrude tightly folded Ordovician Rockley Volcanics of the Macquarie Arc, dominated by greenschist-faces meta-volcaniclastic and volcanic rocks (Fig. S1; Fowler and Lennox, 1992; Pogson and Watkins, 1998).

\section{Previous studies and new samples}

\subsection{Previous studies}

The Browns Creek Intrusive Complex including the granodiorite (Carcoar Granodiorite), more mafic part near Browns Creek (Long Hill Diorite) and the dykes, has been dated with a variety of isotopic methods (Table 1). For the granodiorite, the zircon $\mathrm{U}-\mathrm{Pb}$ dating method gives somewhat older ages of 430-434 Ma than other methods such as Ar-Ar and Rb$\mathrm{Sr}$ at $407-416 \mathrm{Ma}$ (Table 1). It is the same for the dykes which have slightly older $\mathrm{U}-\mathrm{Pb}$ zircon ages at 436-437 Ma compared with 423-424 Ma using the Ar-Ar method on biotite and hornblende. Microdiorite and skarn near the Browns Creek Mine give ages at $423 \mathrm{Ma}$ and 407 Ma via the K-Ar method on hornblende and Ar-Ar on biotite, respectively (Table 1). To compare with our new zircon $\mathrm{U}-\mathrm{Pb}$ ages, we replotted the zircon data including samples $\mathrm{NH} 29$, 
NH43, NH48 and MG5785 (Fig. 4). A dyke sample NH29 from Kovacs (2000) shows a recrystalized age at $420.4 \pm 4.4 \mathrm{Ma}(2 \sigma)$ and igneous age at $436.3 \pm 5.2 \mathrm{Ma}(2 \sigma)$, and some cores with ages at $2148 \mathrm{Ma}$ and $567 \mathrm{Ma}$. Dyke sample NH43 has a weighted mean zircon ${ }^{206} \mathrm{~Pb} /{ }^{238} \mathrm{U}$ age of 437.1 $\pm 5.9 \mathrm{Ma}$ with no inherited zircon cores (Kovacs, 2000). A granodiorite sample $\mathrm{NH} 48$ has a zircon ${ }^{238} \mathrm{U} /{ }^{206} \mathrm{~Pb}$ weighted mean age of $429.8 \pm 3.4$ Ma with a few inherited zircon cores reported by Kovacs (2000). Using the Pb-evaporation method, Lennox et al. (1998) obtained an age of 426.6 Ma from a Browns Creek granodiorite sample. Sample MG5785 (Lennox et al., 1998) has a weighted mean zircon ${ }^{238} \mathrm{U} /{ }^{206} \mathrm{~Pb}$ age of $434.4 \pm 5.5 \mathrm{Ma}$, with two older ages at $450 \mathrm{Ma}$ and $448 \mathrm{Ma}$ which might indicate the inheritance of the Macquarie Arc or the composite ages of the zircon rims and Precambrian cores.

Ma (Lennox et al., 1998). The ages of surrounding Silurian-Devonian granitic and volcanic rocks intruding/overlying the Adaminaby Group are summarized in Figure 4 and Table 1. The Sunset Hills Granite (Lennox et al., 1998) has a weighted mean zircon ${ }^{238} \mathrm{U} /{ }^{206} \mathrm{~Pb}$ age of 430.1 $\pm 3.7 \mathrm{Ma}$ and has inherited zircon cores with ages of $480 \mathrm{Ma}, 486 \mathrm{Ma}$ and $557 \mathrm{Ma}$. The age of the Canowindra Volcanics is $432.0 \pm 5.0 \mathrm{Ma}$, with inherited cores of 495-1011 Ma detected (Atton, 2013). The Mullions Range Volcanics have a zircon ${ }^{238} \mathrm{U} /{ }^{206} \mathrm{~Pb}$ weighted mean igneous age at $433.5 \pm 4.7 \mathrm{Ma}$ with evidence of recrystallisation at 421.6 $\pm 6.7 \mathrm{Ma}$, and 542-614 Ma inherited cores (Atton, 2013). The Bay Formation has a zircon ${ }^{238} \mathrm{U} /{ }^{206} \mathrm{~Pb}$ weighted mean age of 411.3 \pm 4.9 Ma with 516-715 Ma cores (Atton, 2013).

\subsection{New samples}

Representative samples from the Browns Creek Intrusive Complex and Davies

Creek Granite dykes were chosen for this study, because they were intruded into the Ordovician Macquarie Arc, which could potentially sample the lower crust below the arc exposed at the surface. The whole rock geochemistry and zircon studies of these samples would indicate 
whether these intrusions derived from sources as juvenile as the Macquarie Arc, or less juvenile, due to Gondwanan continental influence. The result could detect what is underneath the Macquarie Arc, the arc itself or the continental basement. For the Browns Creek Intrusive Complex, granodiorite sample 17BC01 (Fig. 5a; Fig. S2a), leucogranite sample 17BC02 (Fig. 5b) and a drill core granodiorite sample (BC06; Fig. 5c) were geochemically analysed. A representative granodiorite sample BC06 was used for zircon studies. To our knowledge, the Davies Creek Granite has no previous zircon U-Pb ages, and no Hf or Nd isotope data reported. In most of the outcrops, only aplite dykes are apparent, but no typical granite country rocks crop out (Fig. 5d; Fig. S2b, c). Therefore, we studied two aplite dyke samples 17DC01, 02 (Fig. 5e; Fig. S2d) using zircon U-Pb-Hf analyses. Sample locations are presented in Figure 1, Figure S1 and Supplementary 2 ds1.

Sample 17BC01 is medium-grained granodiorite (Fig. 5f) with a fine-grained granodiorite xenolith (17BC01i; Fig. S2e). Plagioclase is euhedral, altered and zoned, and quartz shows undulose extinction. Hornblende and plagioclase are interlocked in the xenolith. Sample 17BC02 is medium-fine grained leucogranite dominated by quartz and plagioclase with a small amount of biotite and hornblende (Fig. 5g). Quartz exhibits undulose extinction. Sample BC06 is medium-grained granodiorite with $40-50 \%$ plagioclase, $30 \%$ quartz, $15-20 \%$ hornblende and biotite, and small amounts of smaller K-feldspar grains (Fig. S2f). Plagioclase is altered with dusty appearance and some of the crystals are zoned. Some quartz grains show corrosion embayment. Hornblende is more common than biotite. A late quartz vein in this sample may indicate a late thermal event superimposed on the granite (Fig. S2g). Sample 17DC01 is fine-grained foliated granite (aplite) with coarser grained quartz and plagioclase at 1-2 mm (Fig. 5h) and it has some granophyric textures. A fabric is given by weak orientation of sericite, representing a late deformation event. Sample 17DC02 is fine-grained foliated 
granite (aplite) with granophyric and myrmekite textures (Fig. 5i). Biotite grains show flexure. Muscovite veins indicate a superimposed hydrothermal event (Fig. S2h).

\section{Analytical methods}

\subsection{SHRIMP zircon U-Pb analyses}

Zircons were separated by initial rock crushing to fine sand size, sieving, washing and then heavy liquid and magnetic separations. Zircon concentrates were further purified by hand-picking under a binocular microscope at the Institute of Hebei Regional Geological Survey, China. Selected zircons and reference zircons Temora 2 were cast into epoxy resin. After polishing the mounts, cathodoluminescence (CL) images were obtained via the Scanning Electron Microscope JSM-6490 MonoCL4 at the University of Wollongong (UOW).

Zircon U-Pb analyses were performed using the SHRIMP RG instrument at the Australian National University (ANU), following the methods described by Williams (1998). The primary $\mathrm{O}_{2}$-ion beam intensity was 4-6 nA. Each site was rastered for 120 s prior to analysis and the spot size was $\sim 15-20 \mu \mathrm{m} .{ }^{206} \mathrm{~Pb} /{ }^{238} \mathrm{U}$ was calibrated using the Temora standard $(417$ Ma, Black et al., 2003), and U abundance was calibrated using the reference zircon SL13 (U = $238 \mathrm{ppm}$ ) in a set-up mount. The raw data were reduced using the ANU application POXI-SC, and then plotted and assessed using Isoplot 4.1 (Ludwig, 2003). The data are presented in Supplementary 2 ds2 (Mean age calculations are presented at $2 \sigma$ ).

\subsection{Zircon Hf isotopes}

Zircon Hf isotope analyses were conducted on a ThermoFinnigan Neptune multi-collector ICPMS with $193 \mathrm{~nm}$ excimer laser system at ANU, following the protocols by Hiess et al. (2009). The laser was fired at a repetition rate of $5 \mathrm{~Hz}$ with the energy density at $10 \mathrm{~J} / \mathrm{cm}^{2}$ with a square $42 \times 42 \mu \mathrm{m}$ spot. Analysis of a gas blank and a suite of 6 reference 
zircons (Mud Tank, QGNG, 91500, Plesovice, FC-1 and R-33) with varying ${ }^{176} \mathrm{Hf} /{ }^{177} \mathrm{Hf}$ and ${ }^{176} \mathrm{Lu} /{ }^{177} \mathrm{Hf}$ ratios were performed after every 10 unknown sample spots as quality control monitors. The results for all reference zircons are within error of accepted values.

The Hf isotope analytical sites coincided with the U-Pb SHRIMP sites, but with the addition of six more analyses on grains with no age determinations. Complete Lu-Hf isotopic data for all samples and reference zircons along with a detailed method description are presented in Supplementary 2 ds 3,4 .

\subsection{Whole rock geochemistry}

Five representative less altered samples (17BC01, 02, BC01, 17DC01, 02) were crushed using a Cr-Ni TEMA mill, and as a consequence $\mathrm{V}, \mathrm{Cr}$, Co and $\mathrm{Ni}$ abundances may be compromised, and are not used in interpretations. The major element analyses were carried out on a SPECTRO XEPOS X-ray fluorescence instrument at UOW, following the protocols of Norrish and Chappell (1977). The uncertainties are $<3 \%$. The trace element analyses were conducted at the ALS Mineral Division, Brisbane, with a 10\% tolerance of error. A prepared sample is digested with four-acid digests (hydrofluoric, perchloric, hydrochloric and nitric acid), and then analysed via Inductively Coupled Plasma-Atomic Emission Spectroscopy (ICPAES) and Inductively Coupled Plasma-Mass Spectroscopy (ICP-MS). In this procedure, accessory phases concentrating the rare earth elements (REEs) may not be totally soluble. The sample results were presented in Supplementary 2 ds5. Further information on standards for quality control monitoring can be obtained from the ALS laboratories.

\section{Results}

\subsection{U-Pb geochronology}

From the Browns Creek Intrusive Complex, 25 grains from sample BC06 were analysed, including three analyses on the zircon margins. These zircons display prismatic to 
stumpy morphology, with aspect ratio ranging from 1:1 to 3:1 (Fig. 6a). Most of the grains have fine-scale oscillatory zoning and some have banded or patchy internal texture. The Th contents mainly range from 158 to 1195 ppm and U contents range from 42 to 534 ppm, with $\mathrm{Th} / \mathrm{U}$ ratios ranging from 0.26 to 0.83 . The weighted ${ }^{206} \mathrm{~Pb} /{ }^{238} \mathrm{U}$ mean age of three zircon margin analyses $(\# 2.1,3.1,13.1)$ is $396.3 \pm 5.7$ Ma $(2 \sigma)$, representing the timing of recrystallisation. The age of predominant igneous zircon is $426.1 \pm 2.2 \mathrm{Ma}(2 \sigma)$ (Fig. 6c, c1). and 7 grains from 17DC01 were analysed. Most grains are prismatic with fine-scale oscillatory zonation and an aspect ratio at $\sim 1: 2$. Some of the grains have obvious recrystalised rims (e.g. \#1.2 in Fig. 6b). Because in the first analytical session sample 17DC02 had three age peaks based on 23 analyses, a second analytical session was undertaken with 5 more analyses on the same sample and 7 analyses on sample 17DC01. Thorium contents are 38-393 ppm, U contents are 71-606 ppm and $\mathrm{Th} / \mathrm{U}$ ratios are $0.38-0.76$. Although there are only 7 analyses on sample 17DC01, it shows the same age range as sample 17DC02. Thus, the data from both samples are treated together (Fig. 6d, d1). Analysis \#10.1 in the middle of the grain with ${ }^{206} \mathrm{~Pb} /{ }^{238} \mathrm{U}$ age at 381.3 Ma was deemed as a $\mathrm{Pb}$ loss spot based on a second analyses on the margin of the same grain \#10.2 with a marginally older age of 393.9 Ma (Fig. 6b). Analysis \#2.1 is similar to \#10.1 with an age at 385.4 Ma. Therefore, these two analyses are interpreted as displaying ancient loss of radiogenic $\mathrm{Pb}$ and were not included in the weighted mean age calculation. Using the Gaussian deconvolution method in Isoplot (Ludwig, 2003), the other 33 analyses display three main components at 394.6 $\pm 3.4 \mathrm{Ma}, 417.4 \pm 4 \mathrm{Ma}$ and 434.7 $\pm 3.0 \mathrm{Ma}(2 \sigma)$ (Fig. 6d, d1). Based on the occurrence of the samples (aplite dyke) and CL images, 394.6 $\pm 1.7 \mathrm{Ma}$ represents the dyke igneous age (e.g. \#1.2) and 434.7 \pm 1.5 Ma represents the inherited granite age (Davies Creek Granite age). 417.4 \pm 2 Ma may represent a composite age of the dyke and 
the Davies Creek Granite, or a separate recrystallization event, which is not possible to resolve from the CL images (e.g. \#11.1).

\subsection{Hf isotopic composition}

Lu-Hf isotope analyses were performed on 22 grains of sample 17DC02. The result shows initial ${ }^{176} \mathrm{Hf} /{ }^{177} \mathrm{Hf}$ values ranging from 0.2824 to 0.2826 . Initial $\varepsilon \mathrm{Hf}(\mathrm{t})$ values range from -5.1 to +4.7 when calculated by their corresponding weighted mean ages at $394 \mathrm{Ma}$, 417 Ma and 435 Ma (Figs. 6d, 7; Supplementary 2 ds5).

\subsection{Whole rock geochemistry}

Three representative samples $\mathrm{BC} 01,17 \mathrm{BC} 01$ and 17BC02 from the Browns

Creek Intrusive Complex, and two samples 17DC01 and 17DC02 from the Davies Creek

Granite dykes were analysed. Davies Creek dykes and 17BC02 fall in the granite field in the TAS (total alkali silica) diagram (Fig. 8a) with peraluminous affinity (Fig. 8b). Samples 17BC01 and BC06 are granodiorite with metaluminous affinity (Fig. 8a, b). Davies Creek dykes have strong $\mathrm{Nb}, \mathrm{Sr}$ and $\mathrm{Ti}$ negative anomalies, while Browns Creek granites have no obvious Sr anomaly, and less negative Ti anomaly (Fig. 8c). In the REE diagram, Davies Creek dykes have relatively higher $\Sigma$ REE, stronger Eu negative anomaly and variable Ce content than the Browns Creek Intrusive Complex samples (Fig. 8d). The Ce positive anomaly of sample 17DC02 (Fig. 8c, d) may be due to high monazite (Ce) content. The Davies Creek samples have slightly lower fractionation with $\mathrm{La} / \mathrm{Yb}(\mathrm{N})$ ranging from 3.0 to 5.1 than the Browns Creek Intrusive Complex with $\mathrm{La} / \mathrm{Yb}(\mathrm{N})$ at 4.5-7.9 (Supplementary 2 ds5).

In the composition-temperature diagram (Fig. 8e), the zircon saturation temperature of the Davies Creek samples is between $800^{\circ} \mathrm{C}$ and $850^{\circ} \mathrm{C}$. Sample $16 \mathrm{BC} 02$ from the Browns Creek Intrusive Complex is between $750^{\circ} \mathrm{C}$ and $800^{\circ} \mathrm{C}$ and two other samples are lower than $700^{\circ} \mathrm{C}$. Most Davies Creek and Browns Creek samples fall in a volcanic arc field 
except sample 17DC02 is on the boundary to oceanic ridge granite (Fig. 8f) or within-plate granite field (Fig. 8g).

267

\section{Discussion}

\subsection{Zircon U-Pb ages and tectonic setting of the granitic rocks}

6.1.1 Zircon U-Pb ages

271

For these granitic rocks, we conclude that there are two intrusive phases and one thermal/deformation event. Phase1 (430-437 Ma; Fig. 3) is represented by Davies Creek Granite age (17DC01, 02; Fig. 6d) and some Browns Creek samples (NH29, NH43, NH48 and MG5785) including Browns Creek granodiorite and some dykes, which is coeval with the Sunset Hills Granite and Canowindra Volcanics at $430 \mathrm{Ma}$ and 432 Ma respectively (U-Pb age; Table1). Phase 2 is the second intrusive phase at 420-426 Ma (Figs. 3, 6a, 6c), represented by Browns Creek granodiorite (BC06) and some dykes (NH29; Fig. 4a); The Browns Creek granodiorite (BC06) igneous age reported here is $426.1 \pm 2.2 \mathrm{Ma}$ which is indistinguishable from 426.6 \pm 2.3 Ma obtained by Lennox et al., (2005) using the Pb-evaporation method (Table1). It is the same phase as the $425 \mathrm{Ma}$ Wyangala Granite and the Barry Granodiorite d; Fig. 3).

The Ar-Ar (on biotite and hornblende) ages of the Browns Creek basaltic dyke are 424-427 Ma (Table 1) which may correspond with the phase 1 (430-437 Ma), while the ArAr ages (on biotite and hornblende) of the Browns Creek granodiorite at 414-416 Ma (Table 1) are consistent with the Barry Granodiorite Ar-Ar age, and a Rb-Sr (on biotite) age of $407 \mathrm{Ma}$ 

correspond to the post-magmatic thermal event of recrystallization phase 3 (Fig. 3a). Samples with ages determined using Rb-Sr and Ar-Ar analysis on biotite or hornblende, show younger ages than using the zircon $\mathrm{U}-\mathrm{Pb}$ dating method. This is because hornblende and biotite have lower closure temperature than the magmatic granite crystallization dated by $\mathrm{U}-\mathrm{Pb}$ zircon (Ickert and Williams, 2011; Lennox et al., 1998; Lennox et al., 2005), and consequently the ages determined by different methods can vary by 2-28 million years for these rocks (Lennox et al., 2005). Another factor is that the biotite or hornblende may be affected by the late

\subsubsection{Tectonic setting}

Phase 1 (430-437 Ma): Most of the Browns Creek samples fall in the volcanic arc field as also some of the coeval S-type granites (e.g. Cowra Granodiorite; Fig. 8f, g). Because the Browns Creek Intrusive Complex is coeval with the S-type granites, it probably has the same setting as the S-type granite, which is related to crustal thickening associated with the Late Ordovician to Early Silurian Benambran Orogeny (Collins and Hobbs, 2001; Glen et al., 2007). Ickert and Williams (2011) suggested the S-type granites occurred in a supra-subduction zone setting which is the continuation of subduction-related magmatic activity from the Macquarie Arc.

Phase 2 (420-426 Ma) is consistent with the Wyangala Granite crystallisation age at $425 \mathrm{Ma}$ (Lennox et al., 2005). The $417 \mathrm{Ma}$ age apparent in the Davies Creek samples may be a composite age of the dyke and inherited granite. Or it could be related to the isotopic resetting or regional cooling during uplift of the country granites associated with the Bindian event 
has also been reported by Lennox et al. (2005) in relation to new biotite growth in the Browns Creek granodiorite.

Phase 3 ( 396 Ma) may be a thermal phase, and correlates with a 396 Ma event reported in eastern Tasmania (McClenaghan and Higgins, 1993; Reed, 2001). Other deformation events at 387-363 Ma in this area have been reported based on the mica from the shear zones by the Ar-Ar dating method (Glen et al., 1999; Lennox et al., 2014; Lennox et al., 1998; Packham et al., 1999). As indicated by Lennox et al. (2005), there is a 2-28 million years interval between granite crystallisation and hornblende closure. Therefore, this thermal event may be in the same deformation event related to pre- to syn- Tabberaberan event (Spaggiari et al., 2003; Willman et al., 2002).

\subsection{Zircon inheritance and Hf isotope signatures}

In this study, zircon populations from the Davies Creek and Browns Creek granitic rocks provided no obvious xenocrysts. However, Kovacs (2000) reported the presence of inherited cores from Browns Creek granodiorite with no ages presented, but also some from the dykes (Mine Dyke Group) with core ages of $567 \mathrm{Ma}$ and $2148 \mathrm{Ma}$ (Fig. 4a). There are some younger inherited ages from the Browns Creek granodiorite reported by Lennox et al. (2005) at $448 \mathrm{Ma}$ and $450 \mathrm{Ma}$, which may represent inheritance from the Macquarie Arc or the composite age of older zircon core plus the rim. Some Early Ordovician to Cambrian zircon cores are also reported in the surrounding Silurian Sunset Hills Granite which intrudes into the Adaminaby Group (Lennox et al., 2005; Figs. 1, 4e). A similar range of Gondwanan derived zircon cores (495-1011 Ma) are observed in equivalent Silurian-Devonian volcanic units, including the Canowindra Volcanics, Mullions Range Volcanics and the Bay Formation, which unconformably overlie the Ordovician Adaminaby Group and Macquarie Arc (Figs. 1, 4f-h). The inherited cores from the Browns Creek dykes (Mine Dyke Group) may indicate the existence of a Precambrian basement beneath the Macquarie Arc, given that very few if any 
Precambrian zircons are present in the Macquarie Arc which displays a distinctly Ordovicianonly zircon range (Zhang et al., 2019a).

Although very few inherited zircon xenocrysts occur in the Davies Creek dykes and Browns Creek Intrusive Complex, the Hf, $\mathrm{Nd}$ and $\mathrm{Sr}$ isotopic compositions suggest the influence of ancient continental crust. The initial $\varepsilon H f$ values $(-5.1$ to +4.7$)$ of the Davies Creek dykes indicate older continental crust contributed to the magma. If the magma was sourced exclusively from the root of the intra-oceanic Macquarie Arc which has been shown to have very few inherited zircons and mostly juvenile initial $\varepsilon H f$ values in zircons of +8 to +15 (Fig. 7a, b), the initial $\varepsilon H f$ in zircons from Davies Creek dyke would be similar to those in the host Macquarie Arc rocks. Therefore, there must be significantly older continental basement or Gondwana-derived sedimentary units such as the Adaminaby Group underneath the Macquarie Arc, which contributed to the aplite dykes. Comparisons with zircons from the Delamerian and eastern Lachlan granites as well as detrital zircons from the Ordovician Adaminaby Group turbidite, show that the Davies Creek dyke has almost the same range of $\varepsilon H f$ values as Delamerian granite at -6.6 to +4.66 , and the Davies Creek dyke zircon Hf isotopic signature is similar to the eastern Lachlan granites that have evolved from early Silurian juvenile monzonites to late Silurian evolved granites (Fig. 7b). Similarly, the Browns Creek Intrusive Complex initial $\varepsilon N d$ isotope values range from -5.9 to +2.44 which are distinctly less radiogenic (less juvenile) than the Macquarie Arc rocks that they intrude, but almost congruent with the Delamerian granites (Fig. 7c). It is also between the juvenile Macquarie Arc and evolved eastern Lachlan granite (Fig. 7c), representing an evolved magma source. The overall initial ${ }^{87} \mathrm{Sr} /{ }^{86} \mathrm{Sr}$ value ranges from 0.7045 to 0.7065 (Kjolle, 1997; Kovacs, 2000), which is consistent with late Delamerian A-type granite ${ }^{87} \mathrm{Sr} /{ }^{86} \mathrm{Sr}$ values at $0.7041-0.7060$ (Turner and 362 Foden, 1996), and within the range of typical Lachlan Orogen I-type granite values of 0.7045363 0.712, but lower than the S-type granites of 0.709-0.718 (Chappell et al., 1990; King et al., 
1997; McCulloch and Chappell, 1982). This indicates the Browns Creek Intrusive Complex was probably derived from pre-Macquarie Arc felsic sources ultimately of igneous origin. Combining with the rare zircon inheritance of the Browns Creek Intrusive Complex and Hf values of the Davies Creek dykes, both these intrusions may be mainly derived from deep ancient continental crust underneath the Macquarie arc (e.g. Delamerian granite), with possibly some contamination of the Adaminaby Group and Macquarie Arc.

\subsection{Geochemistry}

The Browns Creek Intrusive Complex and Davies Creek dyke that intrude into the mafic rocks Macquarie Arc contain rare zircon xenocrysts, compared with abundant xenocrysts in the coeval S-type granites (e.g. Cowra Granodiorite, Sunset Hills Granite) and equivalent volcanic rocks (e.g. Canowindra Volcanics) that intrude/overlie the Adaminaby Group. This reflects the fact that they were derived from different source rocks, or the same source (Adaminaby Group) with just higher temperature resulting the melting of the zircon xenocrysts.

The Davies Creek dykes are low in $\mathrm{Rb}$ and alumina, has higher $\mathrm{Na}_{2} \mathrm{O} / \mathrm{K}_{2} \mathrm{O}(0.9$ 1.5; Supplementary 2 ds5) and largely lacking in inherited zircons, which contrasts with the classic S-type Silurian Cowra Granodiorite and Roseburg and Sunset Hills Granite (Fig. 8g, b). Higher $\mathrm{Rb}$ and alumina content in S-type magmas is provided by the incongruous melting of biotite and muscovite originally present in the clay-rich turbidites and shales of the Adaminaby Group source rocks (Offler and Fergusson, 2016). On the other hand, the dykes were sourced from the country rocks of the Davies Creek Granite, as shown by the mixed zircon ages (Fig. $6 b, d)$. Thus, the Davies Creek Granite is possibly from sources with average granitic to tonalite composition, marked by much lower mica content and consequently lower volatile content. This is also shown in the melt composition diagram (Fig. 9) that the Davies Creek Granite 
samples from previous studies mainly fall in the tonalite field, and dyke samples from this study are in the granite field. The zircon saturation diagram shows the likely magma temperature of the Davies Creek Granite dykes are around $820^{\circ} \mathrm{C}$ (Fig. 8f). As shown by experimental work (e.g., Patino Douce, 2004 and references therein), the melting temperature of such sources in the lower crust are high $\left(800-850^{\circ} \mathrm{C}\right)$, meaning they can dissolve considerably more zircon until they become saturated in zirconium. Thus, the magma temperatures of the Davies Creek Granite are high, reducing the possibility of preserving inherited zircon from the source rocks. Thus, the Davies Creek Granite is mainly derived from the melting of lower crust with a granitic-tonalite composition.

Some of the Browns Creek samples (e.g. BC06) have much lower Rb and alumina and higher $\mathrm{Na}_{2} \mathrm{O} / \mathrm{K}_{2} \mathrm{O}$ (e.g. $\mathrm{BC} 06=2.36$ ) compared with the typical S-type Cowra Granodiorite and Roseburg and Sunset Hills Granites (Fig. 8b, g). The melt composition diagram (Fig. 9) shows most of the Browns Creek Intrusive Complex samples falling in the tonalite and granodiorite fields and some in the granite field. However, the likely magma temperature of some granodiorites (e.g. $\mathrm{BC} 06,17 \mathrm{BC} 01)$ have similar magma temperature at $600-700^{\circ} \mathrm{C}$ with the S-type granite and some I-type (e.g. Barry Granite; Fig. 8e), and some (e.g. 17BC02) have a likely magma temperature of $750-800^{\circ} \mathrm{C}$ (Fig. 8e). According to the melting composition experiments, the lower crust melting starts at $\sim 650^{\circ} \mathrm{C}$ in metasedimentary rocks (Hermann, 1997 and references therein) but at higher temperature $\left(\sim 800-850^{\circ} \mathrm{C}\right)$ for the tonalitic rocks (Patino Douce, 2004) and the widespread melting in middle crust occurs at $409 \sim 700^{\circ} \mathrm{C}$ (Harris et al., 1995). Considering some Browns Creek samples have lower magma temperature as the S-type granite $\left(600-700^{\circ} \mathrm{C}\right)$ but with rare zircon xenocrysts, the possible 411 source material of the Browns Creek Intrusive Complex is likely from middle to lower crust 412 with a mixed component of granitic-tonalitic crystalline and sedimentary rocks of the 413 Adaminaby Group. 
Based on the initial zircon $\mathrm{Hf}$ and whole rock Nd isotopic compositions of the Browns Creek and Davies Creek intrusions (Fig. 7), the Macquarie Arc is most likely to represent an extensive thrust sheet derived from Panthalassa ocean, which was emplaced onto the Gondwana crust, with geochemical and isotope signatures more like Delamerian crystalline rocks than the Adaminaby Group sedimentary rocks. This thrust sheet was disrupted by later folding and faulting (e.g. Glen and Watkins, 1999). This supports the hypothesis that the Macquarie Arc is not a deeply rooted autochthonous arc but rather more likely to be an allochthonous klippe (Aitchison and Buckman, 2012) (Figs. 2a, 10). Therefore, from this perspective, the Macquarie Arc was much less likely initiated via continually west dipping subduction with back-arc spreading (Cawood et al., 2009; Collins, 2002; Glen, 2013), or amalgamation of the terranes only through the rotation (Fergusson, 2009; Fergusson and Colquhoun, 2018; Glen et al., 2009), because in either cases it would have the root deep into the lithosphere containing only arc crust from its earliest stages. Further, the seismic reflection profile also detected a non-exposed layer at 20-25 km underneath the Macquarie Arc (Glen et al., 2002), which was suggested as Cambrian-Ordovician MORB volcanic rocks.

\subsection{Implications}

Zircon inheritance studies of post-collision granites have the potential to provide important information relating to the deep structure of the lower crust. It-could be widely applied to other proposed exotic terranes to deduce the composition and nature of inaccessible basement. Even in the cases, where there are no inherited zircons being detected, the zircon $\mathrm{Hf}$ isotope or whole rock $\mathrm{Nd}$ studies can still reveal if the magma has ancient continental contamination or not (e.g., Jeon and Williams, 2018; Nutman et al., 2008). 


\section{Conclusions}

439

1) The Browns Creek granodiorite from this study has an igneous age of 426.1 22.2 Ma upon which an event caused recrystallization at 396.3 Ma. The Davies Creek dyke has an igneous age of 394.6 $\pm 3.4 \mathrm{Ma}$, and Davis Creek Granite age is 434.7 $\pm 1.5 \mathrm{Ma}$. These granites have three main phases: Phase 1 is an intrusive event at 430-437 Ma related to widespread extension following the Benambran Orogeny at about the Ordovician-Silurian boundary. Phase 2 is the second intrusive event at $420-426$ Ma. Phase 3 is a recrystallization event at 395-396 Ma which is likely related to the pre-Tabberabberan Orogeny.

2) The Browns Creek Intrusive Complex and Davies Creek dyke intrude into the juvenile Macquarie Arc but display significantly low zircon initial $\varepsilon \mathrm{Hf}(-5.1$ to +4.7$)$ and whole rock initial $\varepsilon N d$ values ( -5.9 to +2.44 ; Kjolle, 1997; Kovacs, 2000), and contain rare Cambrian and older zircon xenocrysts. These suggest the Gondwanan continental crust may underlie the Macquarie Arc and contributed to these lower crustal melts. Therefore, the Macquarie Arc is less likely to represent a deeply rooted autochthonous arc but rather an allochthonous island arc that was thrust over the Gondwanan continent.

3) Both studied granites have very rare pre-Ordovician zircon xenocrysts and lower $\mathrm{Rb}$ content than the coeval S-type granites, and they have similar evolved $\mathrm{Hf}$ and $\mathrm{Nd}$ isotope values as the Delamerian granites. These indicate the continental basement underneath the Macquarie Arc is probably dominated by Delamerian granitic-tonalitic crystalline rocks with possibly some sedimentary rocks of the Adaminaby Group which are derived largely from erosion of the Delamerian Orogen.

\section{Acknowledgements}

This study is supported by GeoQuest Research Centre, University of Wollongong and the China Scholarship Council (No.201506400054). We give our thanks to 
463 Jessica Walsh and Ryan Manton for assistance in the field. Thank you to Chris Fergusson and 464 Lloyd White for helpful discussions. Yang Song assisted with zircon separation of the Davies 465 Creek Granite dyke samples. Tom McMahon assisted with CL imaging on the SEM at UOW 466 Electron Microscopy Centre. Paul Carr and Jose Abrantes assisted with sample preparation and 467 whole rock major element XRF analyses. We thank Dr Robin Offler and an anonymous 468 reviewer providing detailed comments for improvement.

469 Data availability: Analytical data of this study are available in Supplementary 1-2.

470 


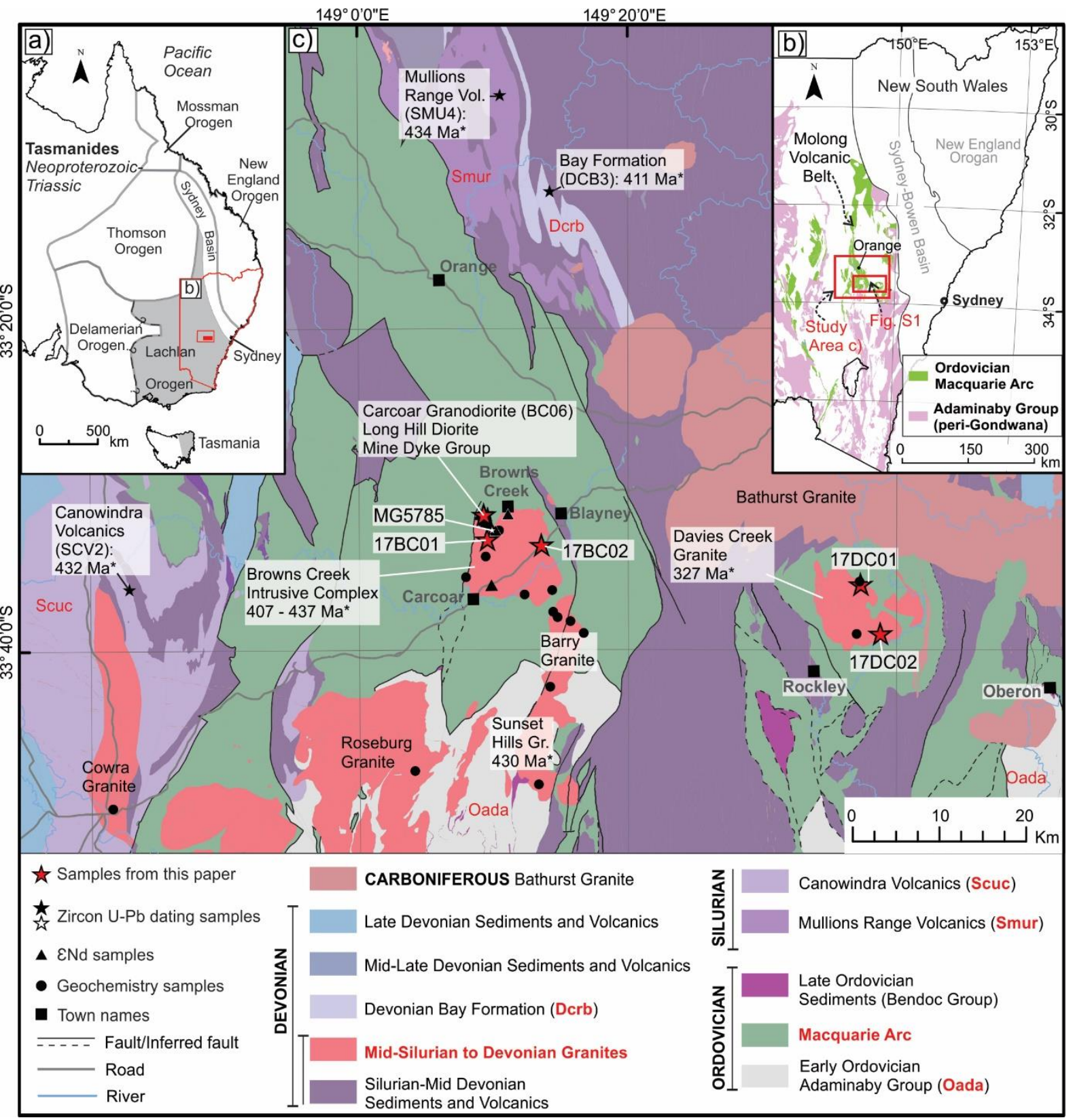

Fig. 1. a) Orogenic belts of the Tasmanides in eastern Australia (after Glen, 2005, 2013). b) with sample localities. Maps b, c are after Colquhoun et al. (2017). A detailed map of the study area (Fig. 1b) can be found in Supplementary 1 Fig. S1. Detailed locations of samples from this study are presented in Supplementary 2 ds1. *These ages are from previous studies and detailed references are given in Table 1. 


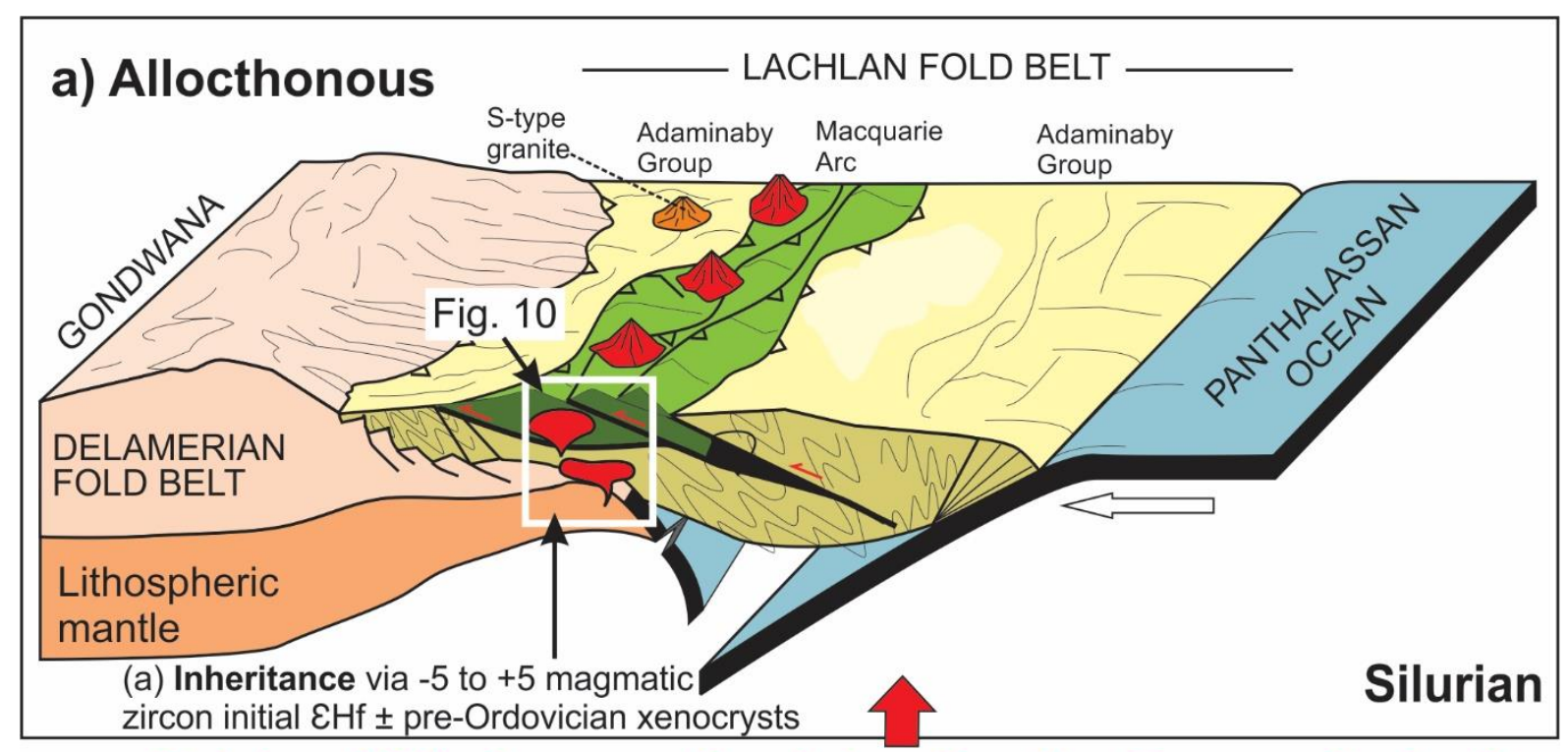

(a) Inheritance via -5 to +5 magmatic
zircon initial $\varepsilon H f \pm$ pre-Ordovician xenocrysts

Silurian

Origin of Silurian granites intruding the Macquarie Arc?

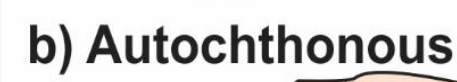

S-type granite

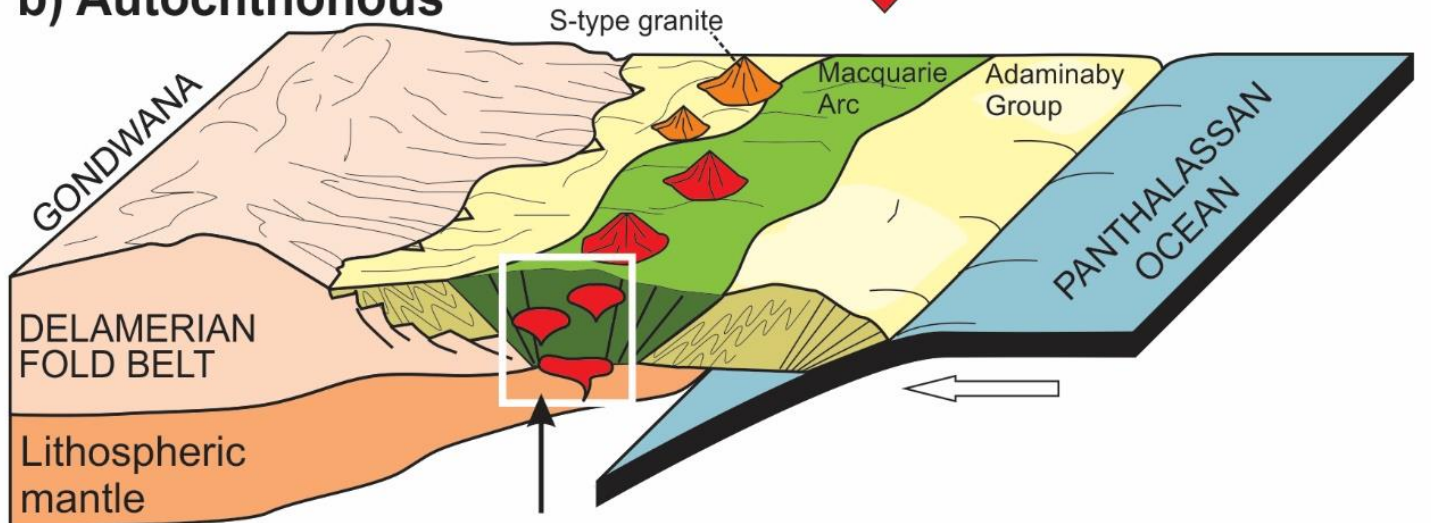

(b) No inheritance via +8 to +15 magnetic zircon initial $\mathcal{E} \mathrm{Hf}$ and no pre-Ordovician xenocrysts

Silurian

Fig. 2. Two proposed emplacement mechanisms of the Macquarie Arc into the middle of the Adaminaby Group (After Aitchison and Buckman, 2012). a) The Macquarie Arc was thrusted onto the passive margin of eastern Gondwana as an allochthonous terrane. In this case, the Macquarie Arc is thin-skinned with no 'root' deep into the lithosphere. The post-collisional granites intruded into the arc would possibly have inherited zircons and less juvenile affinity compared with the juvenile arc via initial $\varepsilon \mathrm{Hf}$. b) The Macquarie Arc was initiated via continued western subduction in a back-arc setting and ended up with the closure the back-arc as an autochthonous terrane. In this model, the 

granites would have juvenile zircons and almost no pre-Ordovician zircon inheritance. 

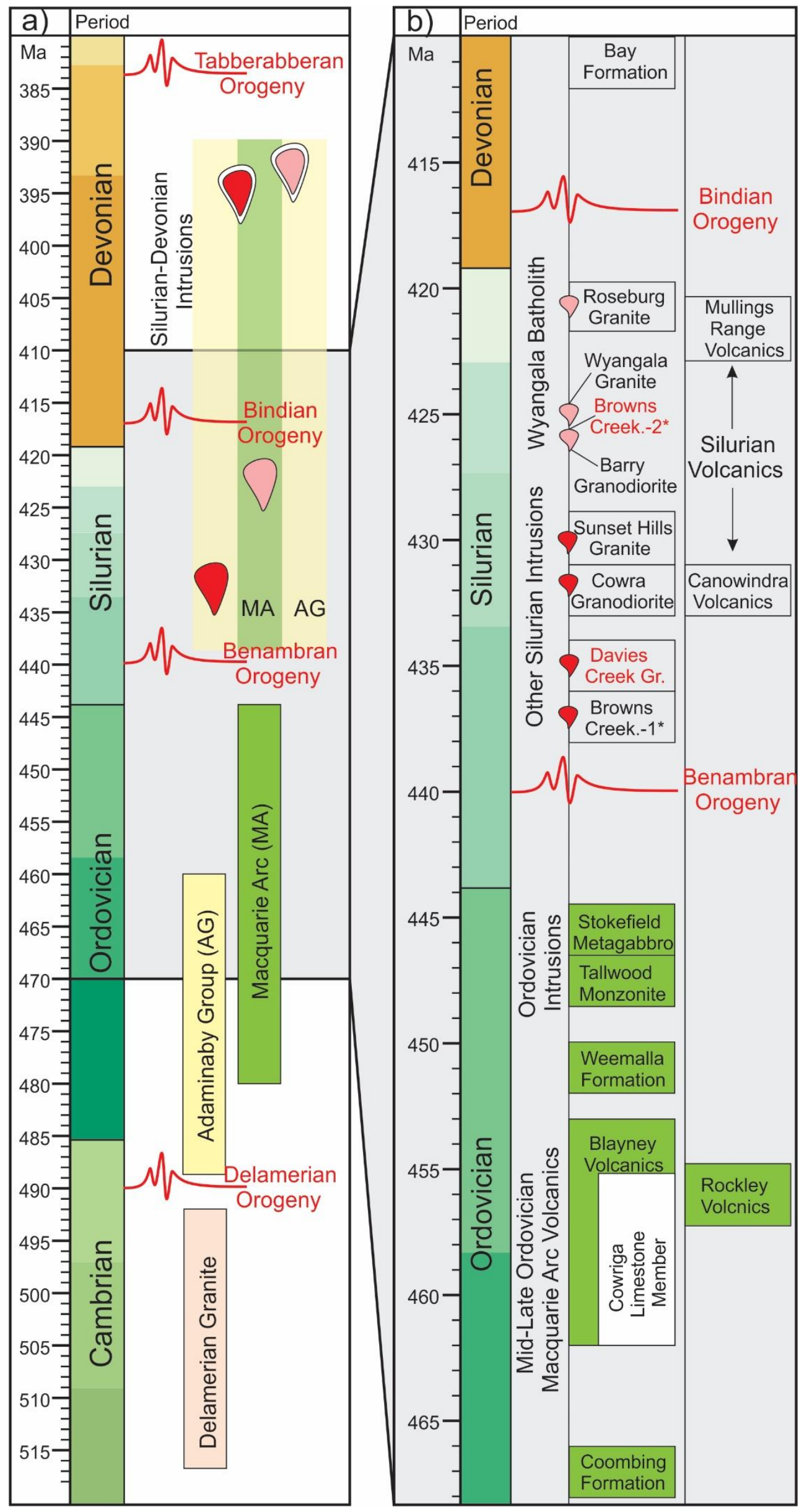
Fig. 3. a) Simplified stratigraphy of the Lachlan Orogen with orogenic events from Cambrian to Devonian. The orogenic events are after Glen (2013), Glen et al. (2007) and Fergusson (2017). The red intrusion (pluton) symbol represents intrusion phase 1 of this study, the pink intrusion symbol represents phase 2, and intrusion symbols with a white rim represent the phase 3 thermal/deformation and recrystallization event. These symbols are also applicable to Fig. 3b. b) Stratigraphy of the study area. *Browns Creek.-1 represents phase 1, and Browns Creek.-2 means phase 2 intrusion. Data sources: Unit names in red colour indicate the ages are from this study. The Cowra Granodiorite is calculated after Glen et al. (2016). Other Silurian unit ages are from previous study (details are present in Fig. 4 caption and Table 1). The Ordovician unit ages: Weemalla Formation is after Zhang et al. (2019b), the Stokefield Metagabbro and Tallwood Monzonite are after (Pogson and Watkins, 1998), the Coombing Formation is after Meffre et al. (2007). 

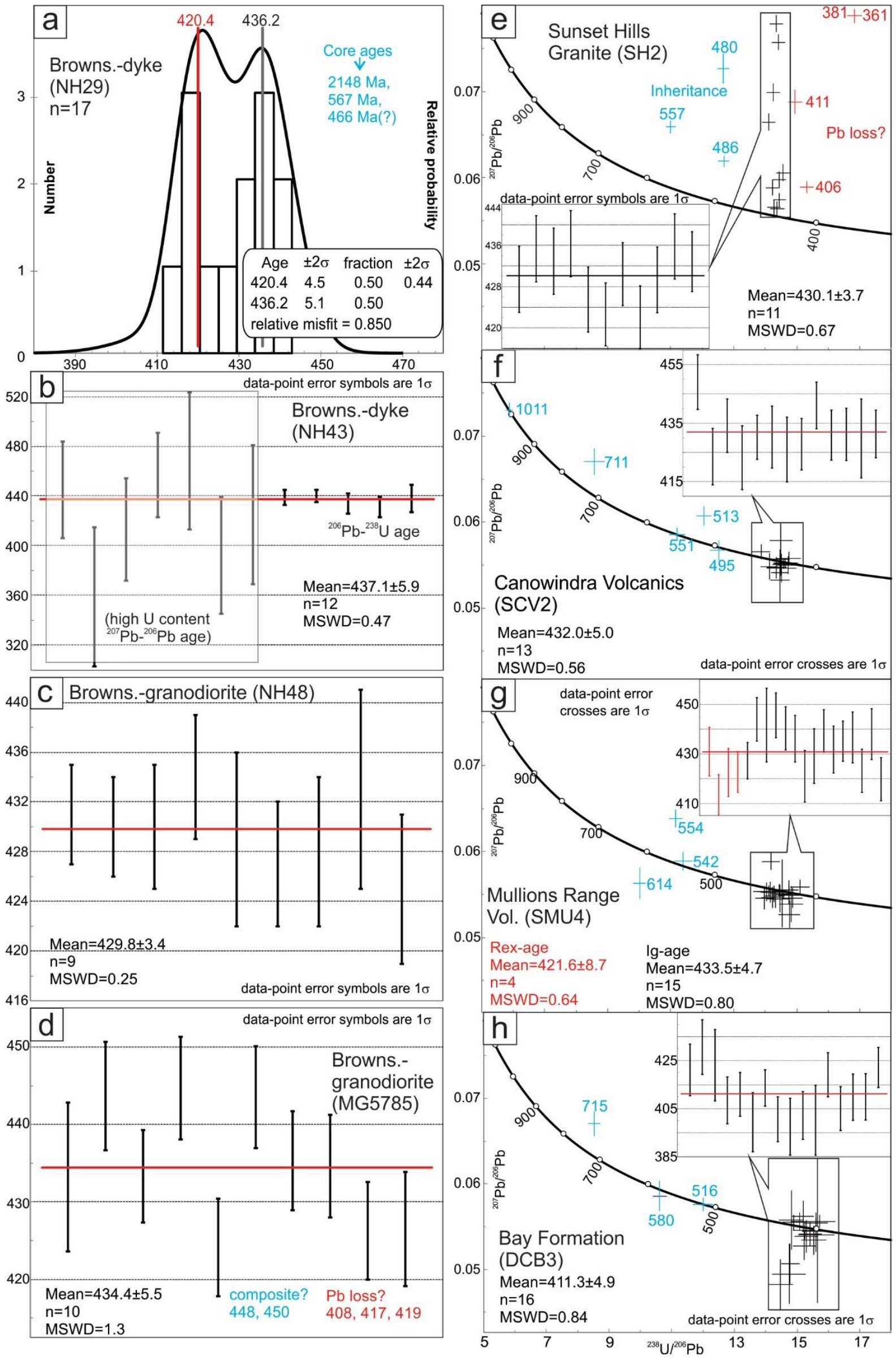
Fig. 4. Zircon U-Pb ages from previous studies. a) Sample NH29 has two igneous ages and has pre-Ordovician inheritance. b) For sample $\mathrm{NH} 43$ (b), ${ }^{207} \mathrm{~Pb} /{ }^{206} \mathrm{~Pb}$ ages were used for calculation when zircons have U content >1000 ppm. c) Sample NH48 has a weighted mean age of 429.8 Ma. d) Sample MG5785 has a weighted mean age of 434.4 Ma and possibly has Ordovician inheritance. e) Sample SH2 has a weighted mean age of 430.1 Ma and Ordovician-Cambrian inheritance. f) Sample SCV2 has a weighted mean age of 432.0 Ma and pre-Ordovician inheritance. g) Sample SMU4 has an igneous age at 433.5 Ma, a recrystallisation age at 421.6 Ma ( $\operatorname{Rex}=$ recrystallisation) and preOrdovician inheritance. Data sources: Samples NH29, 43, 48 (a, b, c) are after Kovacs (2000), samples MG5785 (d) and SH2 (e) are after Lennox et al. (2005), samples SCV2, SMU4 and DCB3 (f, g, h) are after Atton (2013). 
a) $17 \mathrm{BC} 01$

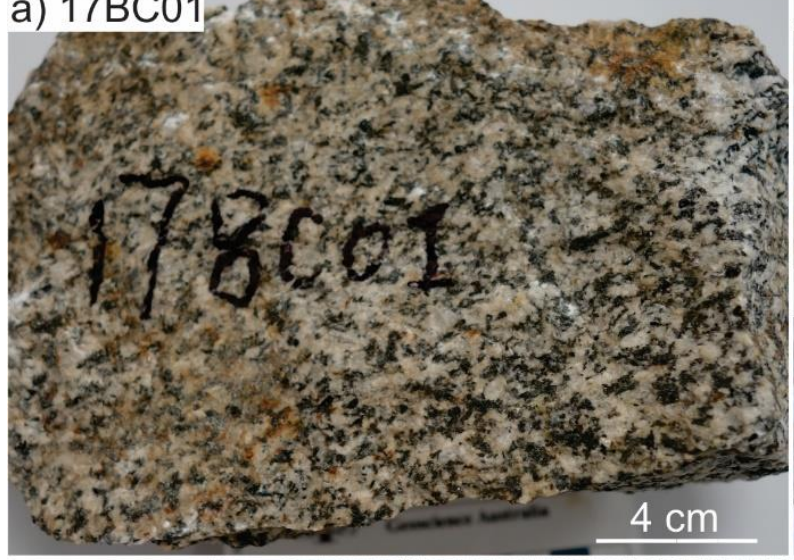

d) $17 \mathrm{DC0} 2 \quad 238^{\circ}$
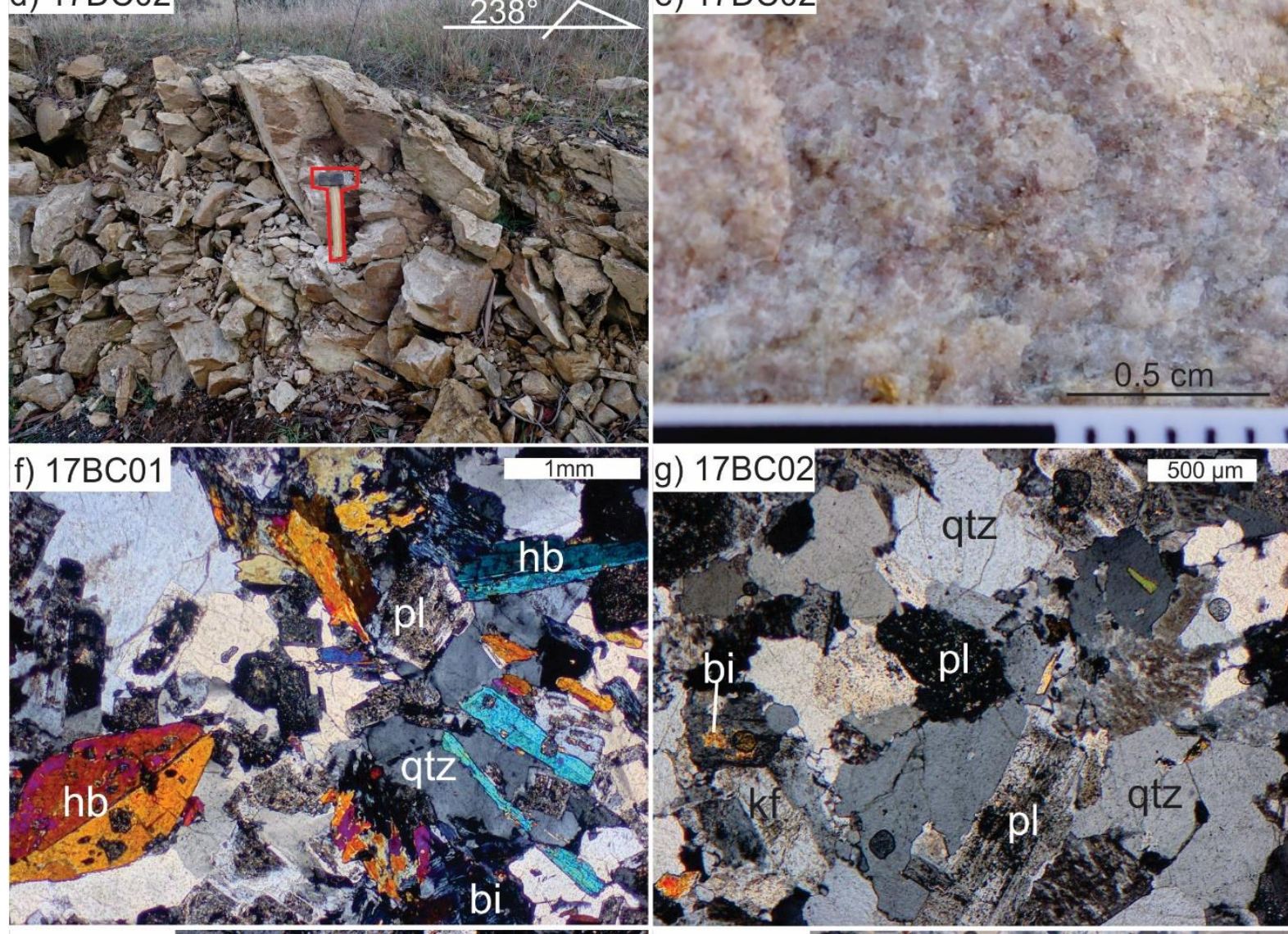

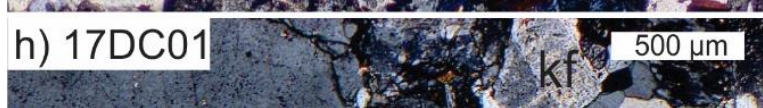
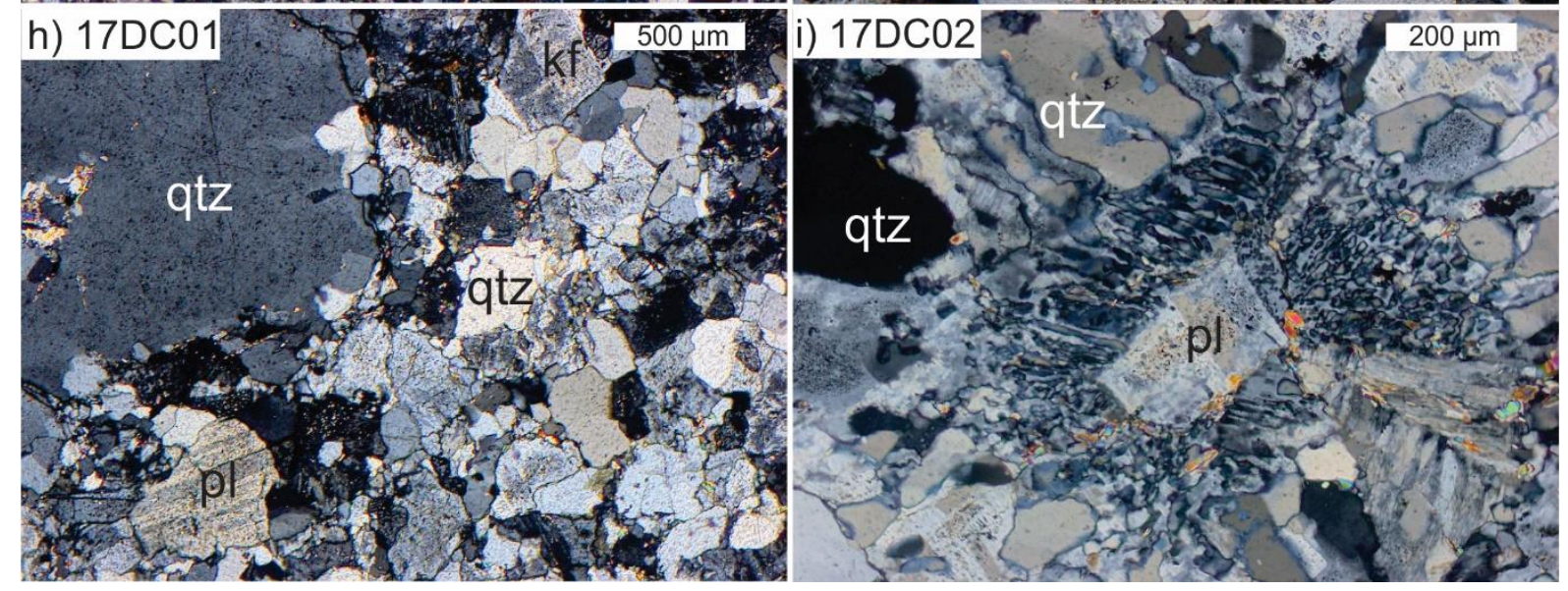

b) $17 \mathrm{BC} 02$

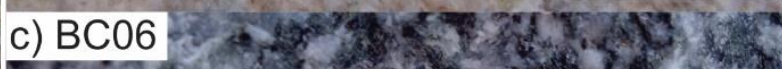

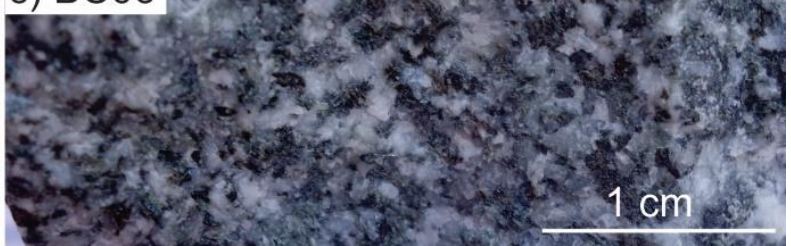

e) $17 \mathrm{DC} 02$

g) $17 \mathrm{BC0} 2 \mathrm{sc}$

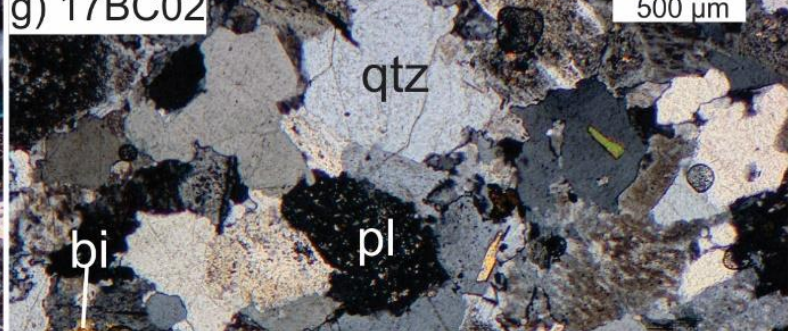

- 15

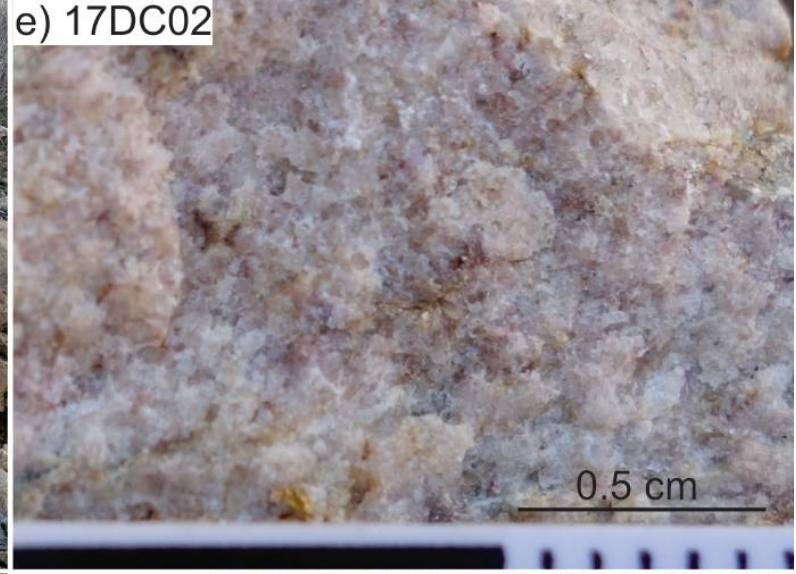

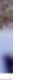


Fig. 5. a) Browns Creek granodiorite sample (17BC01). b) Browns Creek leucogranite sample (17BC02). c) Browns Creek granodiorite (BC06) from drill core. d) Field occurrence of Davies Creek Granite dyke (17DC02: 33³9'2.00"S, 149³8'46.00"E). e) Davies Creek dyke sample (17DC02). f) Photomicrographs of the Browns Creek granodiorite (17BC01) with xenolith (Fig. S2a). g) Browns Creek leucogranite (17BC02). h-i)

Davies Creek dyke samples. i) Granophyre with graphic intergrowths of quartz and plagioclase. Abbreviations: qtz-quartz, hb-hornblende, pl-plagioclase, bi-biotite, musmuscovite. 

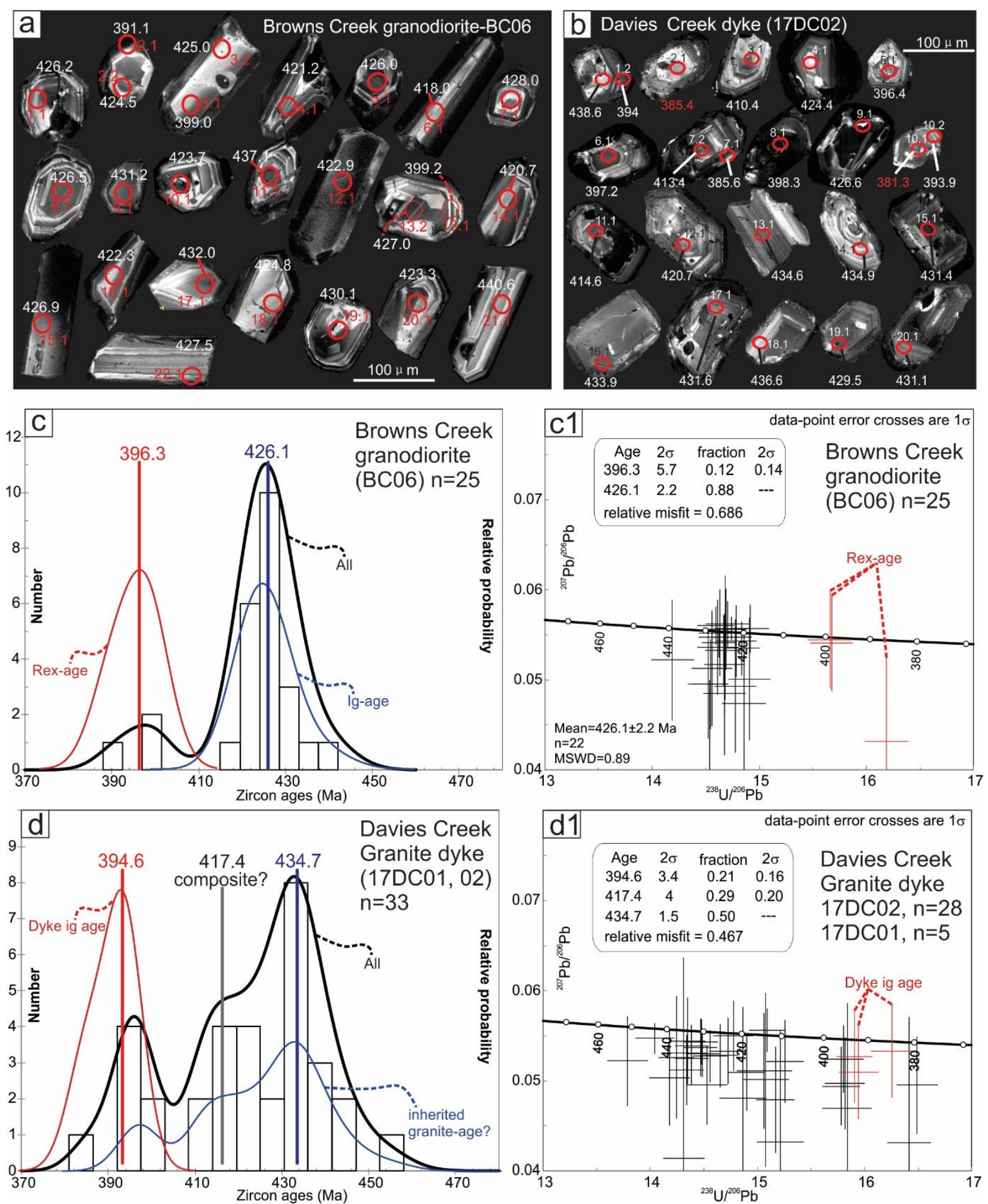

Fig. 6. Representative CL images (a, b) and zircon U-Pb age results of the Browns Creek granodiorite and Davies Creek dyke. c, c1) Sample BC06 has an igneous age of 426.1 Ma and recrystallisation age of 396.3 Ma. d, d1) Samples 17DC01, 02 have a dyke igneous age of 394.6 Ma and inherited granite age of 434.7 Ma. Rex-age = recrystallisation age; Ig-age = Igneous age 


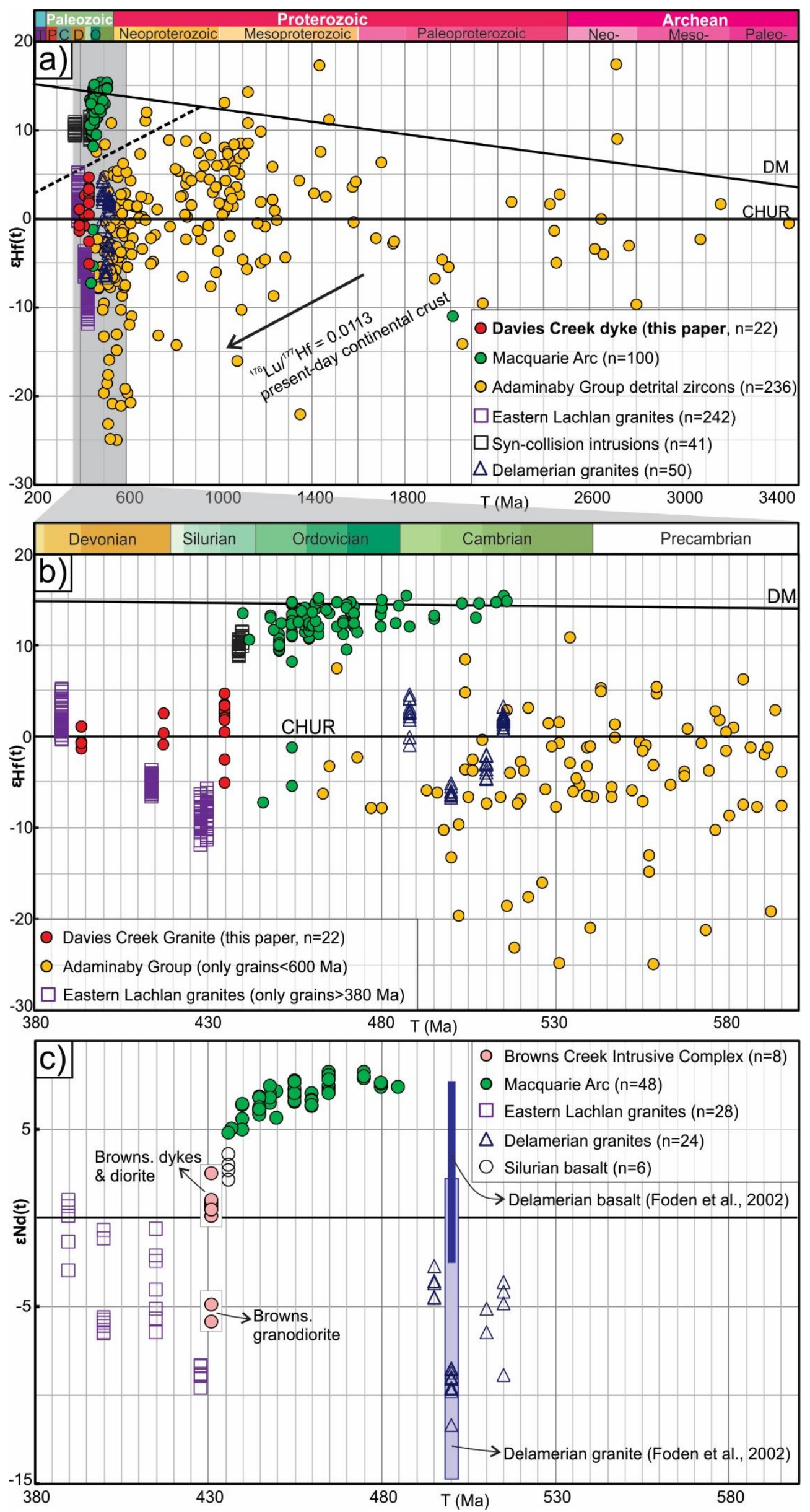


Fig. 7. Zircon Hf isotope data for the Davies Creek dyke (red dots in a, b). a, b) Hf isotope comparisons of Eastern Lachlan granites (Kemp et al., 2009), Macquarie Arc volcanic and volcaniclastic rocks (Glen et al., 2011; Zhang et al., 2019a; Zhang et al., 2019b), Adaminaby Group sedimentary rocks (Glen et al., 2017) and Delamerian granites (Kemp et al., 2009). Symbols in (a) are applicable to (b). c) Whole rock Nd isotope comparisons of the Browns Creek Intrusive Complex (Kjolle, 1997; Kovacs, 2000), Eastern Lachlan granites (Kemp et al., 2009), Macquarie Arc (Crawford et al., 2007) and Delamerian granites (Foden et al., 2002; Kemp et al., 2009). 

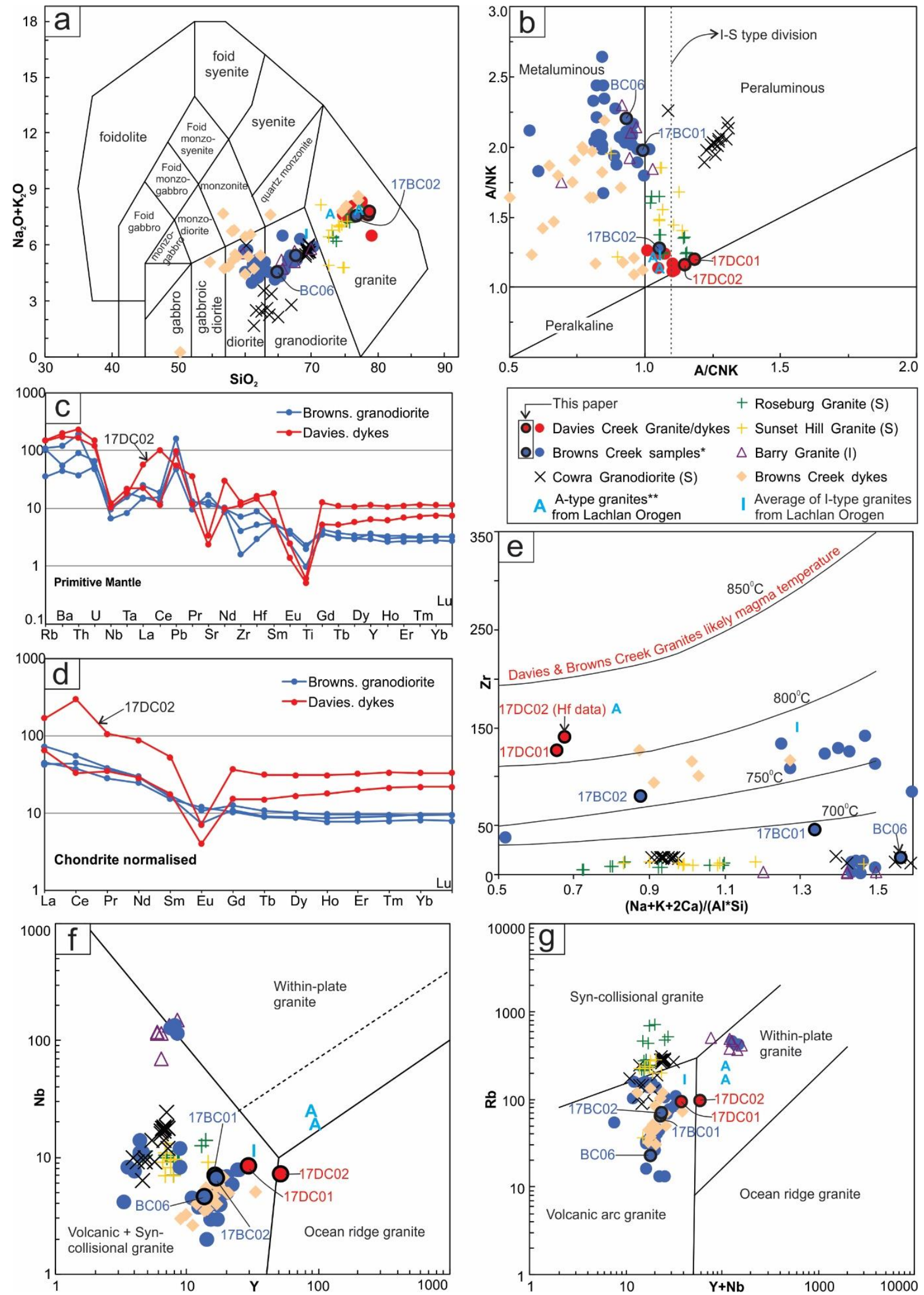

542 Fig. 8. Whole rock geochemistry of the Browns Creek granodiorite and Davies Creek dyke, and comparisons with nearby Silurian-Devonian granites in the Blayney-Rockley area 
including typical S-type granite (e.g. Cowra Granodiorite) and average data of typical I- and A- type granites of the Lachlan Orogen. a) Total alkali vs $\mathrm{SiO}_{2}$ diagram (Middlemost, 1994), b) aluminous classification diagram (Maniar and Piccoli, 1989), c) spider diagram with Primitive mantle normalised, d) REE diagram with Chondrite normalised. c, d) normalisation values are from Sun and McDonough (1989). e) Zircon saturation diagram (Watson and Harrison, 1983), f-g) tectonic setting diagram (Pearce et al., 1984). The legend is applicable to a, b, c, f, g. *Browns Creek samples = Browns Creek Intrusive Complex samples. Data sources: Browns Creek samples of BC06, 17BC01, 02 and Davies Creek samples 17DC01, 02 are from this study. Average of Itype granite is an average of 1074 samples from Lachlan Fold Belt (Chappell et al., 1992). Barry and some Browns Creek samples (including dykes) are from Kovacs (2000) and references therein. **A-type granites are from the Mumbulla Suite (average of 8 analyses) and Gabo Suite (average of 9 analyses) (Collins et al., 1982). Other Browns Creek, Cowra, Davies Creek, Roseburg and Sunset Hills granitic samples are from Geoscience Data Resources compiled by Geological Survey of NSW.

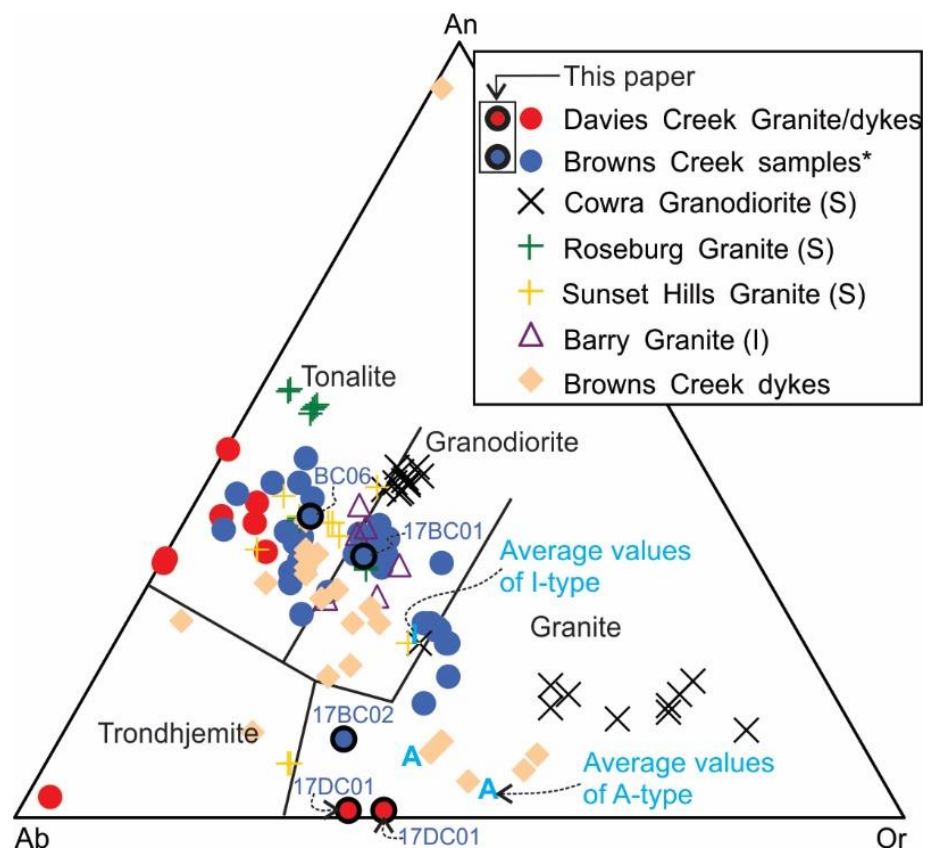



and 17DC01, 02 are from this study. The referenced samples are from the same references as Fig. 8.

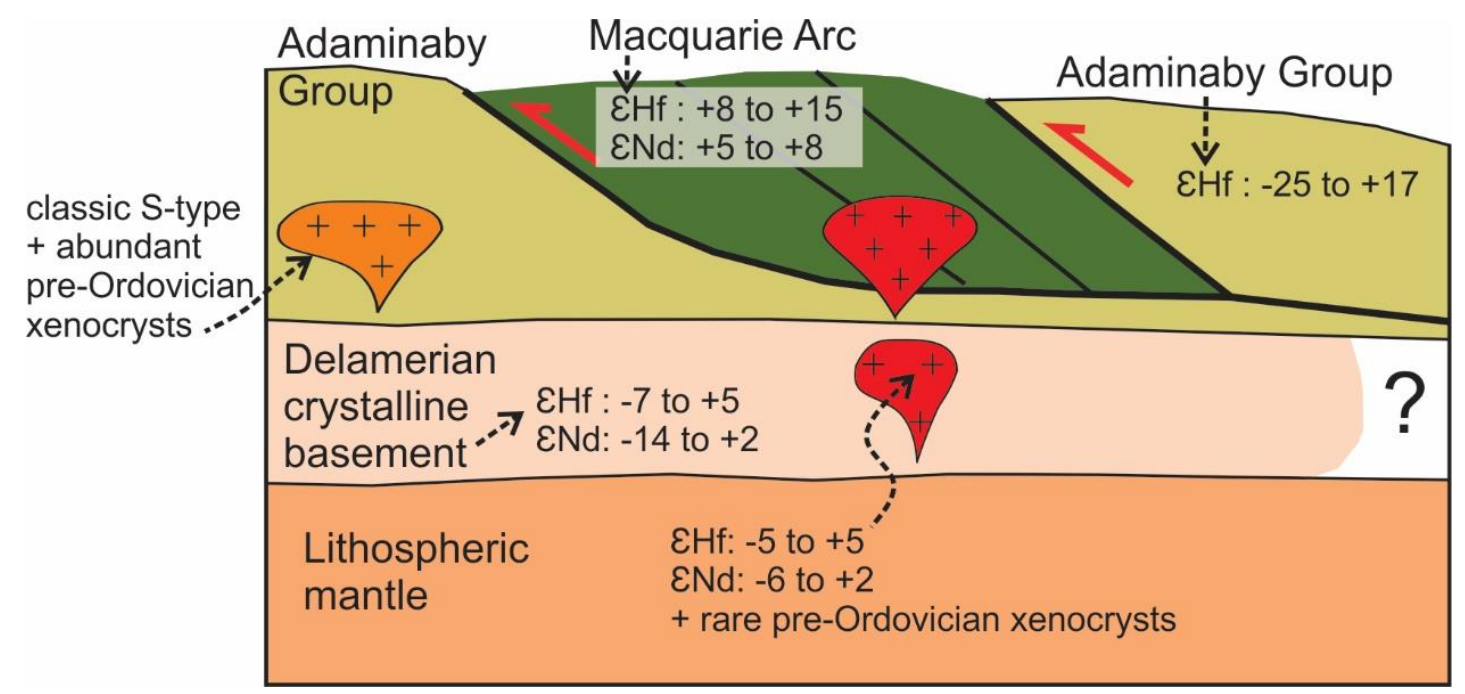

Fig. 10. Emplacement of the allochthonous Macquarie Arc corresponds with the model 1 in Fig. 2a. The Browns Creek Intrusive Complex and Davies Creek Granite dyke intruding into the Macquarie Arc have some (rare) pre-Ordovician zircon xenocrysts and have similar initial $\mathrm{Hf}$ and $\mathrm{Nd}$ isotopes as the Delamerian granites. The result indicates the Macquarie Arc has crystalline basement of significant prehistory and possibly also Adaminaby Group as the footwall to the Macquarie Arc which is an allochthonous klippe. 
572 Granite and related Silurian-Devonian volcanic rocks in Blayney-Rockley area.

\begin{tabular}{|c|c|c|c|c|}
\hline Group & $\begin{array}{l}\text { Igneous age } \\
(\mathrm{Ma})(2 \sigma)\end{array}$ & Method & Mineral & Data source \\
\hline \multicolumn{5}{|l|}{$\begin{array}{c}\text { Browns Creek } \\
\text { Intrusive Complex }\end{array}$} \\
\hline $\begin{array}{c}\text { Mine Dyke Group } \\
\text { (NH29) }\end{array}$ & $436.2 \pm 5.2 *$ & $\begin{array}{c}\mathrm{U} / \mathrm{Pb} \\
(\mathrm{SHRIMP})\end{array}$ & zircon & Kovacs (2000) \\
\hline $\begin{array}{l}\text { Mine Dyke Group } \\
\text { (NH43) }\end{array}$ & $437.1 \pm 5.9$ & $\begin{array}{c}\mathrm{U} / \mathrm{Pb} \\
\text { (SHRIMP) }\end{array}$ & zircon & Kovacs (2000) \\
\hline Basaltic dyke & $426.9 \pm 0.6$ & $\mathrm{Ar} / \mathrm{Ar}$ & $\begin{array}{l}\text { alteration } \\
\text { biotite }\end{array}$ & Perkins et al. (1995b) \\
\hline Basaltic dyke & $423.6 \pm 1.0$ & $\mathrm{Ar} / \mathrm{Ar}$ & $\begin{array}{l}\text { alteration } \\
\text { biotite }\end{array}$ & Perkins et al. (1995b) \\
\hline Basaltic dyke & $424.4 \pm 1.0$ & $\mathrm{Ar} / \mathrm{Ar}$ & $\begin{array}{l}\text { alteration } \\
\text { hornblende }\end{array}$ & Perkins et al. (1995b) \\
\hline Microdiorite & $423 \pm 12.0$ & $\mathrm{~K} / \mathrm{Ar}$ & hornblende & Perkins et al. (1995a) \\
\hline Skarn & $\sim 407$ & $\mathrm{Ar} / \mathrm{Ar}$ & $\begin{array}{l}\text { alteration } \\
\text { biotite }\end{array}$ & Perkins et al. (1995a) \\
\hline Long Hill Diorite & $418.9 \pm 2.8$ & $\mathrm{Ar} / \mathrm{Ar}$ & hornblende & Perkins et al. (1995b) \\
\hline Carcoar Granodiorite & $426.6 \pm 2.3$ & Pb-evaporation & zircon & Lennox et al. (2005) \\
\hline Carcoar Granodiorite & $407 \pm 4.0$ & $\mathrm{Rb} / \mathrm{Sr}$ & biotite & Lennox et al. (1998)* \\
\hline Carcoar Granodiorite & $414 \pm 8.0$ & $\mathrm{Ar} / \mathrm{Ar}$ & biotite & Perkins et al. (1995b) \\
\hline Carcoar Granodiorite & $413 \pm 8.0$ & $\mathrm{Ar} / \mathrm{Ar}$ & biotite & Perkins et al. (1995b) \\
\hline Carcoar Granodiorite & $416 \pm 2.2$ & $\mathrm{Ar} / \mathrm{Ar}$ & hornblende & Perkins et al. (1995b) \\
\hline $\begin{array}{c}\text { Carcoar Granodiorite } \\
\text { (NH48) }\end{array}$ & $429.8 \pm 3.4$ & $\begin{array}{c}\mathrm{U} / \mathrm{Pb} \\
\text { (SHRIMP) }\end{array}$ & zircon & Kovacs (2000) \\
\hline $\begin{array}{c}\text { Carcoar Granodiorite } \\
\text { (MG5785) }\end{array}$ & $434.4 \pm 5.5^{*}$ & $\begin{array}{c}\mathrm{U} / \mathrm{Pb} \\
\text { (SHRIMP) }\end{array}$ & zircon & Lennox et al. (2005) \\
\hline \multicolumn{5}{|l|}{ Other Groups } \\
\hline Davies Creek Granite & $327 \pm 1.6$ & $\mathrm{Rb} / \mathrm{Sr}$ & biotite & Lennox et al. (1998) \\
\hline Barry Granodiorite & $410.2 \pm 11.6$ & $\mathrm{~K} / \mathrm{Ar}$ & hornblende & Lennox et al. (1998) \\
\hline Barry Granodiorite & $413 \pm 8$ & $\mathrm{Ar} / \mathrm{Ar}$ & hornblende & Lennox et al. (1998) \\
\hline Barry Granodiorite & $408.2 \pm 11$ & $\mathrm{~K} / \mathrm{Ar}$ & hornblende & Lennox et al. (1998) \\
\hline Barry Granodiorite & $425.8 \pm 1.9$ & Pb-evaporation & zircon & Lennox et al. (2005) \\
\hline Sunset Hills Granite & $371 \pm 4$ & $\mathrm{Ar} / \mathrm{Ar}$ & biotite & Lennox et al. (1998) \\
\hline Sunset Hills Granite & $378.8 \pm 8.5$ & $\mathrm{~K} / \mathrm{Ar}$ & biotite & Lennox et al. (1998) \\
\hline Sunset Hills Granite & $363 \pm 2$ & $\mathrm{Rb} / \mathrm{Sr}$ & biotite & Lennox et al. (1998) \\
\hline $\begin{array}{l}\text { Sunset Hills Granite } \\
\text { (SH2) }\end{array}$ & $430.1 \pm 3.7$ & $\begin{array}{c}\mathrm{U} / \mathrm{Pb} \\
\text { (SHRIMP) }\end{array}$ & zircon & Lennox et al. (2005) \\
\hline Wyangala Granite & $425.2 \pm 3.5$ & $\begin{array}{c}\mathrm{U} / \mathrm{Pb} \\
\text { (SHRIMP) }\end{array}$ & zircon & Lennox et al. (2014) \\
\hline $\begin{array}{c}\text { Canowindra Volcanics } \\
\text { (SCV2) }\end{array}$ & $432.0 \pm 5.0^{*}$ & $\begin{array}{c}\mathrm{U} / \mathrm{Pb} \\
\text { (SHRIMP) }\end{array}$ & zircon & Atton (2013) \\
\hline
\end{tabular}




\begin{tabular}{|c|c|c|c|c|}
\hline $\begin{array}{c}\text { Mullions Range } \\
\text { Volcanics (SMU2) }\end{array}$ & $421.6 \pm 8.7^{*}$ & $\begin{array}{c}\mathrm{U} / \mathrm{Pb} \\
\text { (SHRIMP) }\end{array}$ & zircon & Atton (2013) \\
\hline $\begin{array}{l}\text { Bay Formation } \\
\text { (DCB3) }\end{array}$ & $411.3 \pm 4.9^{*}$ & $\begin{array}{c}\mathrm{U} / \mathrm{Pb} \\
(\mathrm{SHRIMP})\end{array}$ & zircon & Atton (2013) \\
\hline
\end{tabular}

573 Note: *samples have inherited zircons, **S. Shaw in Lennox et al., 1998

\section{$574 \quad$ References}

575 Aitchison, J.C., Buckman, S., 2012. Accordion vs. quantum tectonics: Insights into continental growth 576 processes from the Paleozoic of eastern Gondwana. Gondwana Research 22, 674-680.

577 Atton, H., 2013. Tectono-metallogenic evolution of Silurian to Devonian felsic volcanics of the 578 Lachlan Orogen, Orange region, School of Earth and Environmental Sciences. University of Wollongong, p. 158.

Baadsgaard, H., Nutman, A., Bridgwater, D., 1986. Geochronology and isotopic variation of the early Archaean Amitsoq gneisses of the Isukasia area, southern West Greenland. Geochimica et Cosmochimica Acta 50, 2173-2183.

Barker, F., 1979. Trondhjemite: definition, environment and hypotheses of origin, Developments in petrology. Elsevier, pp. 1-12.

Black, L.P., Kamo, S.L., Allen, C.M., Aleinikoff, J.N., Davis, D.W., Korsch, R.J., Foudoulis, C., 2003. TEMORA 1: a new zircon standard for Phanerozoic U-Pb geochronology. Chemical Geology 200, 155-170.

Cawood, P.A., 2005. Terra Australis Orogen: Rodinia breakup and development of the Pacific and Iapetus margins of Gondwana during the Neoproterozoic and Paleozoic. Earth-Science Reviews 69, 249-279.

Cawood, P.A., Kröner, A., Collins, W.J., Kusky, T.M., Mooney, W.D., Windley, B.F., 2009.

Champion, D.C., 2016. Geodynamic synthesis of the phanerozoic of eastern Australia, Second ed. Geoscience Australia, Canberra. 7 Field Guide Excursion A-2, Seventh International Conference on Geochronology, 

Geophysics, Australia, Canberra, p. 96.

Chappell, B.W., White, A.J.R., Hine, R., 1988. Granite provinces and basement terranes in the Lachlan Fold Belt, southeastern Australia. Australian Journal of Earth Sciences 35, 505-521.

Collins, W., Beams, S., White, A., Chappell, B., 1982. Nature and origin of A-type granites with particular reference to southeastern Australia. Contributions to Mineralogy and Petrology 80, 189-200.

605

Collins, W., Hobbs, B., 2001. What caused the Early Silurian change from mafic to silicic (S-type)

Collins, W.J., 2002. Hot orogens, tectonic switching, and creation of continental crust. Geology 30,

608 $535-538$

Colquhoun, G.P., L.Deyssing, Ballard, J.C., Hughes, K.S., Troedson, A.L., 2017. New South Wales

Crawford, A.J., Meffre, S., Squire, R.J., Barron, L.M., Falloon, T.J., 2007. Middle and Late Ordovician magmatic evolution of the Macquarie Arc, Lachlan Orogen, New South Wales. Australian Journal of Earth Sciences 54, 181-214.

Fergusson, C.L., 2009. Tectonic evolution of the Ordovician Macquarie Arc, central New South Australia: a review. Australian Journal of Earth Sciences 64, 1-39. 
Fergusson, C.L., Colquhoun, G.P., 2018. Ordovician Macquarie Arc and turbidite fan relationships, Lachlan Orogen, southeastern Australia: stratigraphic and tectonic problems. Australian Journal of Earth Sciences, 1-31.

Foden, J., Elburg, M.A., Turner, S., Sandiford, M., O'Callaghan, J., Mitchell, S., 2002. Granite production in the Delamerian orogen, South Australia. Journal of the Geological Society 159, $557-575$.

Foster, D.A., Gray, D.R., 2000. Evolution and Structure of the Lachlan Fold Belt (Orogen) of Eastern Australia. Annual Review of Earth and Planetary Sciences 28, 47-80.

Fowler, T., Lennox, P., 1992. Low-pressure deformation of a small high-level pluton: the syn-tectonic Davys Creek Granite from the southeastern Lachlan Fold Belt, NSW. Tectonophysics 214, 293-309.

Glen, R., Lennox, P., Foster, D., 1999. 40Ar-39Ar dating of deformation west of the Hill End Trough, Lachlan Orogen. New South Wales. Quarterly Notes of the Geological Survey of New South Wales 110, 13-22.

Glen, R.A., 2005. The Tasmanides of eastern Australia. Geological Society, London, Special Publications 246, 23-96.

Glen, R.A., 2013. Refining accretionary orogen models for the Tasmanides of eastern Australia. Australian Journal of Earth Sciences 60, 315-370.

Glen, R.A., Belousova, E., Griffin, W.L., 2016. Different styles of modern and ancient non-collisional orogens and implications for crustal growth: a Gondwanaland perspective. Canadian Journal of Earth Sciences 53, 1372-1415.

Glen, R.A., Fitzsimons, I.C.W., Griffin, W.L., Saeed, A., 2017. East Antarctic sources of extensive Lower-Middle Ordovician turbidites in the Lachlan Orogen, southern Tasmanides, eastern Australia. Australian Journal of Earth Sciences 64, 143-224.

Glen, R.A., Korsch, R.J., Direen, N.G., Jones, L.E.A., Johnstone, D.W., Lawrie, K.C., Finlayson, D.M., Shaw, R.D., 2002. Crustal structure of the Ordovician Macquarie Arc, Eastern Lachlan 

348.

Glen, R.A., Meffre, S., Scott, R.J., 2007. Benambran Orogeny in the Eastern Lachlan Orogen, Australia. Australian Journal of Earth Sciences 54, 385-415.

Glen, R.A., Percival, I.G., Quinn, C.D., 2009. Ordovician continental margin terranes in the Lachlan Orogen, Australia: Implications for tectonics in an accretionary orogen along the east Gondwana margin. Tectonics 28, 1-17.

Glen, R.A., Saeed, A., Quinn, C.D., Griffin, W.L., 2011. U-Pb and Hf isotope data from zircons in the Macquarie Arc, Lachlan Orogen: Implications for arc evolution and Ordovician palaeogeography along part of the east Gondwana margin. Gondwana Research 19, 670-685.

Glen, R.A., Watkins, J.J., 1999. Implications of Middle Devonian deformation of the eastern part of the Hill End Trough, Lachlan Orogen, New South Wales. Australian Journal of Earth Sciences 46, 35-52.

Gray, D., Foster, D., 2004. Tectonic evolution of the Lachlan Orogen, southeast Australia: historical review, data synthesis and modern perspectives. Australian Journal of Earth Sciences 51, 773817.

Harris, N., Ayres, M., Massey, J., 1995. Geochemistry of granitic melts produced during the incongruent melting of muscovite: implications for the extraction of Himalayan leucogranite magmas. Journal of Geophysical Research: Solid Earth 100, 15767-15777.

Hermann, J., 1997. Experimental constraints on phase relations in subducted continental crust. Contributions to Mineralogy and Petrology 143, 219-235.

Hiess, J., Bennett, V.C., Nutman, A.P., Williams, I.S., 2009. In situ U-Pb, O and Hf isotopic compositions of zircon and olivine from Eoarchaean rocks, West Greenland: New insights to making old crust. Geochimica et Cosmochimica Acta 73, 4489-4516.

Ickert, R.B., Williams, I.S., 2011. U-Pb zircon geochronology of Silurian-Devonian granites in southeastern Australia: implications for the timing of the Benambran Orogeny and the I-S dichotomy. Australian Journal of Earth Sciences 58, 501-516. 
Jeon, H., Williams, I.S., 2018. Trace inheritance-Clarifying the zircon O-Hf isotopic fingerprint of Itype granite sources: Implications for the restite model. Chemical Geology 476, 456-468.

Jeon, H., Williams, I.S., Chappell, B.W., 2012. Magma to mud to magma: Rapid crustal recycling by Permian granite magmatism near the eastern Gondwana margin. Earth and Planetary Science Letters 319-320, 104-117.

Kemp, A., Hawkesworth, C., Collins, W., Gray, C., Blevin, P., 2009. Isotopic evidence for rapid continental growth in an extensional accretionary orogen: The Tasmanides, eastern Australia. Earth and Planetary Science Letters 284, 455-466.

King, P., White, A., Chappell, B., Allen, C., 1997. Characterization and origin of aluminous A-type granites from the Lachlan Fold Belt, southeastern Australia. Journal of Petrology 38, 371-391.

Kjolle, I., 1997. The setting and genesis of the Browns Creek gold-copper skarn deposit, New South Wales, Australia. Australian National University, p. 193.

Kovacs, N.J., 2000. Magmatic and hydrothermal evolution of the Browns Creek intrusive complex and associated gold mineralisation. Australian National University, p. 202.

Lennox, P., Forster, M., Williams, I., 2014. Emplacement and deformation ages of the Wyangala Granite, Cowra, NSW. Australian Journal of Earth Sciences 61, 607-618.

Lennox, P., Fowler, T., Foster, D., 1998. Barry Granodiorite and Sunset Hills Granite: Wyangalastyle intrusion at the margin of a regional ductile shear zone, northern Lachlan Fold Belt, New South Wales. Australian Journal of Earth Sciences 45, 849-863.

Lennox, P., Trzebski, R., Armstrong, R., Siebel, W., 2005. Structural evolution and granite chronology of the central Molong Zone, eastern Lachlan fold belt, Australia. Australian Journal of Earth Sciences 52, 79-99.

Ludwig, K.R., 2003. User's manual for isoplot 3.00, a geochronlogical toolkit for microsoft excel. Berkeley Geochronology Center, Special Publication 4, 25-32.

Maniar, P.D., Piccoli, P.M., 1989. Tectonic discrimination of granitoids. Geological Society of America Bulletin 101, 635-643. 
McClenaghan, M., Higgins, N., 1993. The age and intrusive relationships of granitoids of the Blue Tier Batholith, north-east Tasmania. Mineral Resources Tasmania Report 33.

McCulloch, M.T., Chappell, B.W., 1982. Nd isotopic characteristics of S-and I-type granites. Earth and Planetary Science Letters 58, 51-64.

Meffre, S., Scott, R.J., Glen, R.A., Squire, R.J., 2007. Re-evaluation of contact relationships between Ordovician volcanic belts and the quartz-rich turbidites of the Lachlan Orogen. Australian Journal of Earth Sciences 54, 363-383.

Middlemost, E.A., 1994. Naming materials in the magma/igneous rock system. Earth-Science Reviews 37, 215-224.

Moorbath, S., Taylor, P.N., Goodwin, R., 1981. Origin of granitic magma by crustal remobilisation: $\mathrm{Rb}-\mathrm{Sr}$ and $\mathrm{Pb} / \mathrm{Pb}$ geochronology and isotope geochemistry of the late Archaean Qôrqut Granite Complex of southern West Greenland. Geochimica et Cosmochimica Acta 45, 10511060.

Norrish, K., Chappell, B.W., 1977. X-ray fluorescence spectrometry, Physical Methods in Determinative Mineralogy, 2nd Edition ed. Academic Press, London, pp. 201-272.

Nutman, A.P., Dawes, P.R., Kalsbeek, F., Hamilton, M.A.J.P.R., 2008. Palaeoproterozoic and Archaean gneiss complexes in northern Greenland: Palaeoproterozoic terrane assembly in the High Arctic. 161, 419-451.

Offler, R., Fergusson, C.L., 2016. Proto-Pacific-margin source for the Ordovician turbidite submarine fan, Lachlan Orogen, southeast Australia: Geochemical constraints. Sedimentary Geology $334,53-65$.

Packham, G., Percival, I., Bischoff, G., 1999. Age constraints on strata enclosing the Cadia and Junction Reefs ore deposits of central New South Wales, and tectonic implications, In: Wales, G.S.o.N.S. (Ed.), Quarterly Notes, pp. 1-20.

Patino Douce, A.E., 2004. Vapor-absent melting of tonalite at 15-32 kbar. Journal of Petrology 46, 275-290.

Pearce, J.A., Harris, N.B., Tindle, A.G., 1984. Trace element discrimination diagrams for the tectonic interpretation of granitic rocks. Journal of Petrology 25, 956-983. 
Perkins, C., McDougall, I., Walshe, J.L., 1995a. Metallogenic epochs of the Tasman Orogen, eastern Australia. AMIRA Project P334A, Annual Report.

Perkins, C., Walshe, J.L., Morrison, G., 1995b. Metallogenic episodes of the Tasman fold belt system, eastern Australia. Economic Geology 90, 1443-1466.

Pogson, D.J., Watkins, J.J., 1998. Bathurst 1: 250000 Geological Sheet SI/55-8: Explanatory Notes. Geological Survey of New South Wales.

Reed, A., 2001. Pre-Tabberabberan deformation in eastern Tasmania: A southern extension of the Benambran Orogeny. Australian Journal of Earth Sciences 48, 785-796.

Rosenbaum, G., 2018. The Tasmanides: Phanerozoic Tectonic Evolution of Eastern Australia. Annual Review of Earth and Planetary Sciences 46, 291-325.

Scheibner, E., Basden, H., 1998. Geology of New South Wales-Synthesis. Volume 2 Geological Evolution-5.

Spaggiari, C.V., Gray, D.R., Foster, D.A., McKnight, S., 2003. Evolution of the boundary between the western and central Lachlan Orogen: implications for Tasmanide tectonics. Australian Journal of Earth Sciences 50, 725-749.

Sun, S.-S., McDonough, W.-S., 1989. Chemical and isotopic systematics of oceanic basalts: implications for mantle composition and processes. Geological Society, London, Special Publications 42, 313-345.

Turner, S., Foden, J., 1996. Magma mingling in late-Delamerian A-type granites at Mannum, South Australia. Mineralogy and Petrology 56, 147-169.

VandenBerg, A., 2000. The Tasman Fold Belt system in Victoria: geology and mineralisation of Proterozoic to Carboniferous rocks. Geological Survey of Victoria, Melbourne, Victoria.

Watson, E.B., Harrison, T.M., 1983. Zircon saturation revisited: temperature and composition effects in a variety of crustal magma types. Earth and Planetary Science Letters 64, 295-304.

Williams, I.S., 1998. U-Th-Pb geochronology by ion microprobe. Reviews in Economic Geology 7 , $1-35$. 
Willman, C., VandenBerg, A., Morand, V., 2002. Evolution of the southeastern Lachlan fold belt in Victoria. Australian Journal of Earth Sciences 49, 271-289.

Zhang, Q., Buckman, S., Bennett, V.C., Nutman, A., 2019a. Inception and early evolution of the Ordovician Macquarie Arc of Eastern Gondwana margin: Zircon U-Pb-Hf evidence from the Molong Volcanic Belt, Lachlan Orogen. Lithos 326, 513-528.

761

Zhang, Q., Buckman, S., Bennett, V.C., Nutman, A., Song, Y., 2019b. Lachlan Orogen, Eastern Australia: Triangle Formation records the Late Ordovician arrival of the Macquarie Arc terrane at the margin of eastern Gondwana. Tectonics. 